Florida State University College of Law

Scholarship Repository

Scholarly Publications

Spring 2000

\title{
Synthetic Leases: Structured Finance, Financial Accounting and Tax Ownership
}

Donald J. Weidner

Florida State University College of Law

Follow this and additional works at: https://ir.law.fsu.edu/articles

Part of the Law Commons

\section{Recommended Citation}

Donald J. Weidner, Synthetic Leases: Structured Finance, Financial Accounting and Tax Ownership, $25 \mathrm{~J}$. CORP. L. 445 (2000),

Available at: https://ir.law.fsu.edu/articles/134

This Article is brought to you for free and open access by Scholarship Repository. It has been accepted for inclusion in Scholarly Publications by an authorized administrator of Scholarship Repository. For more information, please contact efarrell@law.fsu.edu. 


\title{
Synthetic Leases: Structured Finance, Financial Accounting and Tax Ownership
}

\author{
Donald J. Weidner
}

I. INTRODUCTION 446

II. SYNTHETIC LEASES AND STRUCTURED FINANCE ..............................................447

A. Synthetic Leases and Special Purpose Entities............................................447

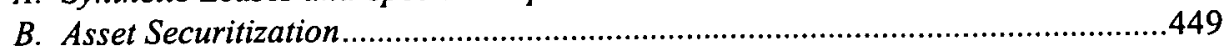

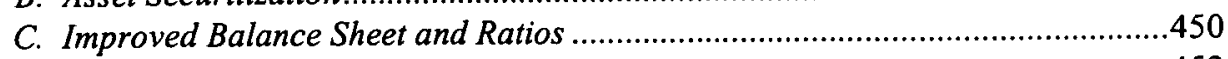

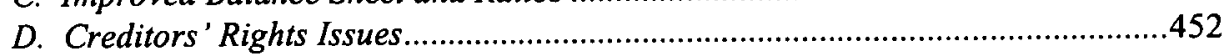

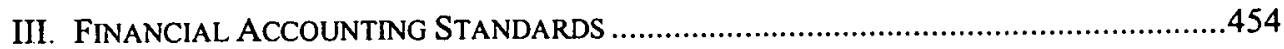

A. Two Ways to Challenge the Transaction ........................................................454

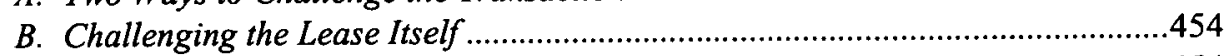

1. FAS 13 and FAS 98..............................................................................454

2. The Four Tests of FAS 13 and Consequences of a Capital Lease.................455

3. The Core "Concept" of FAS 13 ................................................................456

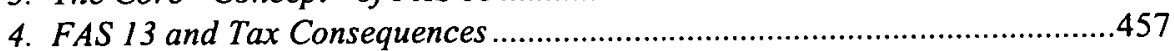

C. Requiring Consolidation of Lessee and Special Purpose Entity.......................458

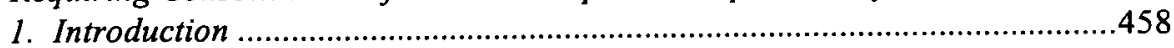

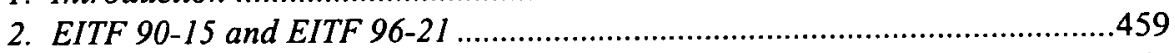

D. SPEs and Professional Test Flunkers ..........................................................462

IV. STATE MORTGAGE LAW OF SUBSTANCE OVER FORM .........................................465

V. FEDERAL INCOME TAX LAW OF SUBSTANCE OVER FORM ....................................465

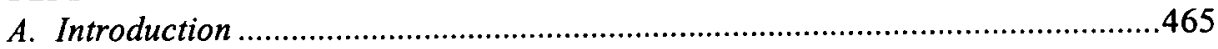

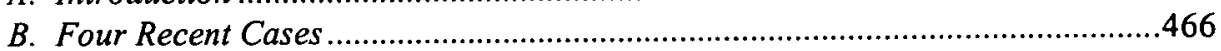

1. Bolger's Building: Nobody Said It Was a Mortgage ..................................467

2. Sun Oil: A Lease Is Deemed a Mortgage..................................................471

3. Frank Lyon Co.: The Supreme Court Fails to Recognize That
a Lease Is a Mortgage .............................................................................475

4. Hilton Reverses Bolger And Narrowly Applies Frank Lyon to
Recharacterize a Lease as a Mortgage .....................................................480

C. The 1999 Advice and the Continued Importance of Sun Oil and Hilton ...........484

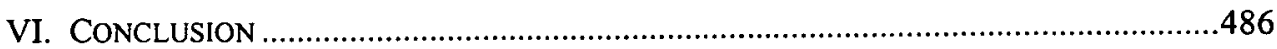

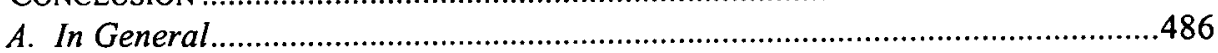

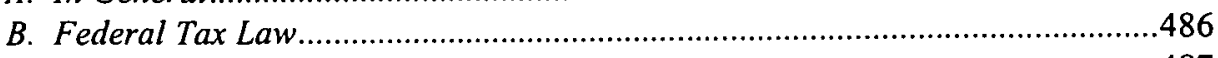

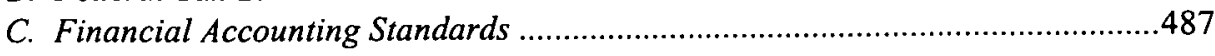


That is the worst of our mortgage deed-owing to the action of equity, it is one long suppressio veri and suggestio falsi. It does not in the least explain the rights of the parties; it suggests that they are other than they really are. ${ }^{1}$

\section{INTRODUCTION}

The term "synthetic lease" is in vogue in the world of commercial real estate finance. In a synthetic lease transaction, money is borrowed based on the financial strength of a tenant of property and on that tenant's agreement to pay rent. The lender expects the debt to be serviced from the rental obligation of the tenant rather than from the financial resources of the nominal owner and borrower. The lease is "synthetic" insofar as it is designed to achieve a blended treatment: the tenant reports it as an operating lease for financial accounting purposes but as a mortgage for federal income tax purposes. This Article explains synthetic lease transactions in the broader context of asset securitization and structured finance and contrasts the treatment of synthetic leases under financial accounting standards and federal income tax law.

For financial accounting purposes, it is relatively easy to keep the debt off a tenant's books. Provided the tenant does not enter into a sale and leaseback, the lease can be structured to "flunk" the tests of the Financial Accounting Standards Board (FASB) that require a lease to be capitalized. ${ }^{2}$ By contrast, for federal income tax purposes, the tenant takes the position that it is the substantive owner under a "benefits and burdens" analysis and, as such, is entitled to depreciation deductions. ${ }^{3}$ Early in 1999, the Office of the Chief Counsel of the Internal Revenue Service (Service) issued a Field Service Advice (Advice) affirming that a benefits and burdens analysis determines the tax treatment of lessees in synthetic lease transactions. ${ }^{4}$ The Advice concluded that a lessee properly claimed to be the "tax owner" of depreciable properties even though it disclaimed ownership for financial accounting purposes.

Although leases have long been treated differently for financial accounting purposes and tax law purposes, the present divergence with respect to synthetic leases is too great. What needs fixing is not the federal income tax law but FASB's financial accounting standards. FASB should eliminate the sharp distinction between sale-leaseback transactions and transactions in which a Special Purpose Entity (SPE) acquires title from a third party. ${ }^{5}$ In particular, FASB should require balance sheet disclosure when the sine qua non of a transaction is an ex ante agreement that the tenant, not the landlord, will report for federal income tax purposes that it is the substantive owner of the encumbered asset.

* Dean and Professor, Florida State University College of Law. B.S., Fordham University, 1966; J.D., 1969, University of Texas at Austin. The author wishes to express his appreciation to his research assistants, Eric Dickey and Peter Fisher, and to Martin J. McMahon, Jr., for his extremely generous and helpful comments. The author served as an expert in two of the referenced disputes.

1. FREDERICH W. MAITLAND, Equity: A COURSE OF LeCTURES 189 (Brunyate ed. 1969).

2. See infra Part III.B.

3. See infra Part V.

4. Internal Revenue Service National Office Field Service Advice, UILC: 61.16 .03 (Jan. 12, 1999) [hereinafter Advice].

5. See infra Part III.B. 


\section{SYNTHETIC LEASES ANd STRUCTUREd FINANCE}

\section{A. Synthetic Leases and Special Purpose Entities}

As was the case with the term "creative financing" that was so popular in the context of residential real estate financing in the 1980 s, the term "synthetic lease" is often used without being adequately defined. Perhaps the best way to define a synthetic lease is first, in terms of the outcome desired by a financier of property and second, in terms of typical features of synthetic lease transactions.

In terms of the desired outcome, a synthetic lease is a transaction in the form of a lease that embodies a blend of characteristics that enables it to be characterized as a lease for financial accounting purposes, while also permitting it to be treated as the nominal tenant's mortgage or "financing transaction" for federal income tax purposes. ${ }^{6}$ Just as the creative financings of the 1980 s generally reflected a return to pre-depression era homefinancing techniques, the term synthetic lease refers to a long-standing dichotomy in the way certain leases are treated for financial accounting purposes as opposed to mortgage and tax law purposes. ${ }^{7}$

For financial accounting purposes, the terms of a synthetic lease are carefully crafted so that the lease will be treated as an "operating lease" rather than as a "capital lease." the lease is a capital lease, the tenant's rental obligations must be capitalized and, hence, reflected on the balance sheet as long-term debt. ${ }^{9}$ On the other hand, if the lease is classified as an operating lease, the rent is treated as an expense during the period in which it is incurred, with the long-term nature of the rental obligation merely reflected in a footnote on the tenant's financial statements. ${ }^{10}$

For federal income tax purposes, a synthetic lease is structured so that the tenant may claim that it is, in substance, the owner of encumbered property, with a rental obligation that should be treated as debt service. Consistent with this view of the underlying substance, the tenant claims a depreciable interest in the building and a depreciable basis that includes the portion of the cost that was financed with borrowed funds. ${ }^{11}$ The tenant claims that, in economic substance, it is depreciating its investment in the building. As a consequence of viewing the rent as debt service, the tenant may deduct only the portion of the "rent" that is traceable to interest and not the portion that is

6. The definition in the Advice refers only to one part of the blend:

A "synthetic lease" or synthetic real estate financing is a method used to provide off-balance sheet financing to a corporate entity for the acquisition and development of a commercial facility or site, with substantial credit support for debt issued by or through an investor or capital source, usually a financial institution.

Advice, supra note 4, at 2 (citing John C. Murray, Off-Balance Sheet Financing: Synthetic Leases, 32 REAL PROP. PROB. \& TR. J. 193, 195 (1997)).

7. See Frank Lyon Co. v. United States, 435 U.S. 561, 577 (1978) (reviewing 536 F.2d 746 (8th Cir. 1976)) ("[T]he characterization of a transaction for financial accounting purposes, on the one hand, and for tax purposes, on the other, need not necessarily be the same.").

8. See infra Part III.B.

9. Id.

10. Id.

11. See infra Part V. 
traceable to repayment of principal. ${ }^{12}$ Especially in the early years of the financing arrangement, the combined depreciation and interest deductions typically exceed the rental deduction.

In short, an investment in a synthetic lease transaction is a high-stakes gamble in the game of form over substance. The bet is that financial accounting standards will honor the transactional form of a lease at the same time that the federal income tax law will perceive that the tenant has made an investment in a depreciable asset with borrowed funds.

As a practical matter, a synthetic lease transaction is usually structured using an SPE. ${ }^{13}$ The entity is "special purpose" in the sense that it is created solely for the purpose of entering into a financing transaction or into a series of financing transactions. Apart from the financing transaction(s), the SPE has no other existence. Indeed, its articles may prohibit any activity other than those necessary to execute a prescribed series of financing transaction documents. The SPE, which probably more often than not is formed with only nominal assets, "purchases" an asset and "borrows" money to finance the acquisition on the strength of a contemporaneous "lease." The lease terms are generally short, frequently three to seven years (not counting renewals), ${ }^{14}$ and usually "triple-net," placing all operating costs-insurance, maintenance, and taxes-on the tenant. The rent payments are generally structured to cover the SPE's debt service and little or nothing more.

It is clear that the tenant's obligation to pay rent is what gives value to the SPE's obligation, which may be supported further by a credit facility. The rent obligation is typically absolute and unconditional, without deduction or set off even in the event of landlord defaults or casualty or condemnation. To emphasize, the tenant's obligation to pay rent may continue even in the event that the SPE is shown to have a complete failure of title. The leases typically place great control in the tenant for extended periods, at least if lease renewal options are considered. The renewal options may be at significantly reduced rent, although stated to reflect some estimate of fair rental value. Finally, the leases may give the tenant options to purchase at prices that are stated to be in terms of market value, but that are depressed by lease renewal options or other factors. ${ }^{15}$

Synthetic leases also contain operating provisions different from other leases. A synthetic lease may provide that the lessee may act for the SPE in a wide variety of situations. For example, it may provide that, in the event of a condemnation, the lessee may negotiate with the condemning authority. The lease may also include presumptions that are not found in "normal" leases. The lease may presume that a wide variety of tenant actions or proposals are taken or offered and approved or accepted, although the SPE may be given a formal opportunity to disapprove or reject. In short, the skids are greased to implement the will of the tenant.

Financial accounting standards are tougher on sale-leasebacks then they are on leases of property the lessor acquires from a third party. ${ }^{16}$ Stated differently, financial

12. Id.

13. See H. Peter Nesvold, What Are You Trying to Hide? Synthetic Leases, Financial Disclosure, and the Information Mosaic, 4 STAN. J. L. BUS. \& FIN. 83, 89 (1999); see also Murray, supra note 6, at 200.

14. As discussed below, a lease will be classified as a capital lease if it is too long or if the rental obligations are too close to the full value of the property. See infra Part III.

15. For other features in synthetic lease transactions, see Murray, supra note 6, at 211.

16. See infra Part III. 
accounting standards more readily classify a lease as a capital lease, rather than as an operating lease, if the lessor traces title back to the lessee. ${ }^{17}$ As a result, the greatest opportunities for synthesis, or blended treatment, lie in new acquisitions rather than in sale-leasebacks. Therefore, the term synthetic lease is most frequently used to refer to transactions that do not involve a sale-leaseback. The user who in substance will own and finance the property avoids holding title immediately prior to becoming a tenant. Instead, the user designates property for the SPE to acquire from a third party, which the SPE acquires and contemporaneously leases to the user. The SPE issues debt to finance what is in form its own acquisition, secured by its mortgage on the fee and by an assignment of its right to collect rent from the user, and perhaps further secured by a credit facility.

\section{B. Asset Securitization}

Synthetic leases of commercial real estate can best be understood in the broader context of asset securitization. ${ }^{18}$ The decades of the 1980 s and 1990 s were characterized by highly competitive business practices. Corporations "downsized" and "restructured"they attempted to define their core missions and to concentrate on what they did best. They "contracted out" functions that could be more effectively served by others. Increasingly, every person and every asset was expected to produce a profit. People and assets came to be viewed as successes or failures based on whether they could function as "profit centers."

Businesses benefit in a variety of ways from breaking up assets into groups or profit centers. For example, a borrower with a modest credit rating might get a very favorable credit rating for a particular transaction by giving a lender a first security interest in the borrower's most choice assets. The borrower can segregate these assets by creating an SPE and by transferring the assets to the SPE, which becomes a nominal borrower. The SPE is "bankruptcy remote" in two ways. First, segregating the assets in an SPE that encumbers them leaves the assets more remote from a bankruptcy of the transferring company. ${ }^{19}$ Second, the SPE itself presents only the most remote chance of becoming

17. Id.

18. Structured financings became so popular that the Securities and Exchange Commission (SEC) in 1992 issued a rule to prevent SPEs from being classified as "investment companies" under the Investment Company Act of 1940, 15 U.S.C. $\S \S 80 \mathrm{a}-1$ to $80 \mathrm{a}-64$ (1994). Rule 3a-7 was issued to "remove an unnecessary and unintended bartier to the use of structured financings in all sectors of the economy." Exclusion from the Definition of Investment Company for Structured Financings, Investment Company Act Release No. IC-19105, 1992 SEC LEXIS 3086, at *1 (Nov. 19, 1992) (codified at 17 C.F.R. pt. 270.3a-7).

19. The use of a bankruptcy-remote SPE raises the question of the enforceability of an arrangement that in effect waives a corporation's right to seek protection of its assets in bankruptcy. Consider, for example, a corporation that finances the assets it needs for daily operations through an SPE that takes title, contemporaneously leases the assets to the corporation, and takes out third-party financing on the strength of the corporation's obligation to pay rent. Is it consonant with the policy of the bankruptcy laws to say that the corporation is denied the protection it would have had if it acquired the assets directly and treated the debt as its own? See Fallick v. Kehr, 369 F.2d 899, 904-05 (2d Cir. 1966) (discussing legislative intent that debtors be permitted to get a fresh start); In re Adana Mortgage Bankers, Inc., 12 B.R. 989, 1009 (N.D. Ga. 1980), vacated, 687 F.2d 344 (11th Cir. 1982) (explaining that a waiver, "even a bargained-for and knowledgeable one, of the right to seek protection of the Bankruptcy Act is void. . ."); In re Weitzen, 3 F. Supp. 698, 698-99 (S.D.N.Y. 1933) (stating that an agreement to waive the benefits of bankruptcy laws is unenforceable). It also raises questions about the rights of the corporation's creditors. See generally Michael J. Cohn, Asset Securitization: How Remote is Bankruptcy Remote?, 26 HofSTRA L. REV. 929 (1998). See also infra Part II.D. 
bankrupt because the SPE does no more than receive the choice assets and become a borrower. Stated differently, the SPE's governing documents provide that it may not engage in any activity that might encumber the choice assets or divert the income stream being used to service the debt.

The choice assets ${ }^{20}$ that are pledged to repay the lender are typically receivables. ${ }^{21}$ In some cases, the choice assets are receivables that are due from third parties. ${ }^{22}$ In others, a receivable is created in the form of a lease to the true borrower. In either event, an SPE is structured to segregate the assets that are used to pay or secure the lender. The lender provides either long-term or short-term debt, based in part on the nature of the receivables. ${ }^{23}$ The restraints on the SPE make it extremely unlikely that the SPE will incur obligations that would jeopardize the secured creditor.

To emphasize, the SPE, not the business that generates the receivables, is the nominal borrower. Depending on the situation, the SPE may issue equity participations and not merely debt. The issuance of securities by these SPEs, formed to acquire receivables and issue securities on the strength of the receivables, is the phenomenon known as asset securitization.

Synthetic leases reflect the securitization of newly acquired real estate assets. The SPE gets favorable financing by issuing notes that are secured by a mortgage of the newly acquired real estate and by an assignment of the SPE's right to collect rent from the user. Favorable financing comes only by further assuring the note purchaser that it will refrain from engaging in any other business that might generate a competing claim to its rent receipts. The notes are, in form, issued by the SPE so that both the assets and the debt are off the lessee's balance sheet. In effect, the lessee has "contracted out" the acquisition, holding of title, and financing of assets that are critical to its trade or business. The allure is that lessees can have their cake and eat it too: within a wide area of operations, form can control substance, whereas in other areas, substance trumps form. A business may say it owns an encumbered asset for some purposes and disclaim both ownership and debt for other purposes.

\section{Improved Balance Sheet and Ratios}

Synthetic leases keep certain assets and liabilities off balance sheet and also improve the ratios by which businesses are judged. In general, a business looks less leveraged when it can take a long-term liability off its books. In addition, the business may improve certain calculations and financial ratios that are often closely monitored. For example, because no asset is booked if a lease is classified as an operating lease, the lessee need not take a charge against earnings for depreciation. This favorably impacts the share

20. Securitization does not always involve choice assets. See Steinhardt Group, Inc. v. Citicorp, 126 F.3d 144 (3d Cir. 1997) (involving the securitization of a pool of delinquent residential mortgage loans and real estate owned by Citicorp as a result of foreclosed loans).

21. See generally Steven L. Schwarcz, Structured Finance: A Guide to the Principles of Asset SeCuRITIZATION (2d ed. 1993).

22. Id.

23. Under section 3(a)(3) of the Securities Act of 1933, sometimes referred to as the "commercial paper exemption," securities with a maturity of nine months or less, the proceeds of which are used for "current transactions," need not be registered. Securities Act of 1933 §3(a)(3), 15 U.S.C. § 77(c)(a)(3) (1994). Some SPEs rely on this exemption to avoid having to register their securities. 
price-to-earnings ratio and the earnings-to-assets ratio. In short, by keeping a heavily encumbered asset off the books, a user may preserve a more favorable return-on-assets ratio, a more favorable return-on-equity ratio, and a more favorable debt-to-equity ratio.

Assume, for example, a very simple balance sheet of Corporation A that shows an asset equal to $\$ 1,000$ in plant and distribution facility, $\$ 1,000$ of receivables, liabilities in the amount of $\$ 1,000$, and shareholder equity in the amount of $\$ 1,000$. Corporation $A$ 's debt/equity ratio is $1 / 1$. If Corporation $A$ takes out a $100 \%$ loan on the receivables, its debt/equity ratio increases to $2 / 1$. If, on the other hand, Corporation $A$ sells the receivables for $\$ 1,000$, its debt/equity ratio remains unchanged. If it uses $\$ 500$ of the $\$ 1,000$ proceeds from the sale to pay off existing debt, its debt/equity ratio improves to $1 / 2.24$

In this situation, an SPE can be created to purchase the receivables from Corporation A. The SPE, rather than Corporation A, issues the debt. The asset the SPE acquires, the receivables, is the income stream the SPE pledges to secure the debt. Rating agencies such as Moody's and Standard \& Poor's rate the SPE's debt on the strength of the payment stream.

Corporation A's real estate can play the same role as its third-party receivables. This situation is more complicated for two basic reasons. First, unlike typical third-party receivables, Corporation A will not want to part with ownership and control of real estate that is essential to its operations. Although Corporation A may be indifferent to parting with technical "ownership," it will insist on retaining control. Second, the real estate itself, unlike the receivables, does not constitute a payment stream. Both differences are addressed by a lease from the SPE to Corporation A. Contemporaneous with a purchase of the land and facility from a third party by the SPE, a lease is created that binds Corporation A to pay rent to the SPE. The rental obligation provides a payment stream to the SPE that is pledged by it to obtain financing. The value of the promise to pay rent is dependent upon the creditworthiness of the tenant rather than the creditworthiness of the SPE, which may have no assets other than title to the property and Corporation A's promise to pay rent.

The value of the lease as security is often enhanced by a "liquidity facility," which is a promise by a third party to make timely payment in the event of the lessee's default. ${ }^{25}$ The liquidity facility can give the SPE's lenders assurance both as to a delay in payment

24. See SCHWARCZ, supra note 21, at 1-3; David Holmes, The Use of Synthetic Leases to Finance Buildto-Suit Transactions, REAL EST. FIN. J., Winter 1996, at 17. See also Howard A. Zuckerman, Lenders Get Creative with New Capital Structure: Synthetic Real Estate Funding, CAPITAL SOURCES FOR REAL ESTATE, December 1995, at 30:

Neither the real estate asset nor the mortgage liability nor the lessor's equity ownership of the facility will appear on the company's balance sheet. Lease payments are classified as an operating expense by the corporate user. Thus, retum on assets, return on equity, and interest coverage ratios are improved relative to an "on balance sheet" debt alternative.

25. See SCHWARCZ, supra note 21, at 13-15. Section 365 of the Bankruptcy Code permits the trustee in bankruptcy to reject, or terminate, an agreement classified as an executory contract. 11 U.S.C. $\$ 365$ (1994). In general, an executory contract is one in which substantial performance remains due on both sides, such that breach by one party of its performance obligations excuses the other side from performing. See, e.g., In re O.P.M. Leasing Servs., Inc., 23 B.R. 104, 117 (Bankr. S.D.N.Y. 1982) (lease is an executory contract because of the lessor's obligation to refrain from interfering with the lessee's right to quiet enjoyment). 
by the lessee and as to a default in payment by the lessee. ${ }^{26}$ Unlike the purchase of the receivables, the SPE also acquires a future interest in the real estate. As discussed more fully below, FASB has addressed both the proper characterization of the leases themselves and whether the relationship between the tenant and the SPE requires consolidated financials. 27

Note that the same principles that apply to removing assets and liabilities from a balance sheet apply to keeping them off in the first place. In the above example, if Corporation A does not yet own the plant and distribution facility, it could choose to acquire the facility through an SPE and then lease the facility. As we are about to see, financial accounting standards are much more advantageous in the case of an acquisition by an SPE from a third party than in the case of a sale-leaseback.

\section{Creditors' Rights Issues}

Although the SPE is created to serve the goals of the lessee, it is also designed to segregate the assets it "purchases" from the lessee's other assets and, more importantly, liabilities. The SPE is made "bankruptcy remote" in the sense that it is to continue, and its payments to its creditors are to continue, even if the lessee becomes troubled or bankrupt. This goal would be frustrated if the lessee were to retain too much control over the SPE or if the lease were not considered a true lease.

If the SPE is owned or controlled by the lessee, the lessee may have the power to cause the SPE to file a voluntary petition for bankruptcy. ${ }^{28}$ Transactions are typically structured to limit the ability of the lessee to cause the SPE to file a voluntary petition. ${ }^{29}$ The charter of the SPE may provide that the SPE may not place itself into bankruptcy unless a certain number of independent directors vote for bankruptcy. ${ }^{30}$ The SPE may be organized with two classes of stock, one to be pledged to the SPE security holders, who must both vote to approve a voluntary filing. ${ }^{31}$ The charter of the SPE may restrict the

\section{See SCHWARCZ, supra note 21 , at 14 :}

When the securities issued by the [SPE] are sold in a public offering, it is not uncommon to see a third party, typically rated AAA by Standard \& Poor's Corp. and Aaa by Moody's Investors Service, Inc., . . . take at least a portion of the risk of nonpayment. For example, the third party may issue a surety bond or other financial guaranty in support of the securities issued by the [SPE], causing such securities to be rated AAA/Aaa. That would often occur where the receivables are novel or do not have a well-established record of payment. The financial guaranty, although costly, provides the assurance needed to sell the [SPE]'s securities in the public markets at investment grade prices.

27. See infra Part III.

28. See 11 U.S.C. $\$ 301$ (1999) (defining the commencement of a voluntary bankruptcy filling). See generally Lynn M. LoPucki, The Essential Structure of Judgment Proofing, S1 STAN. L. REV. 147 (1998).

29. See SCHWARCZ, supra note 21 , at $18 \mathrm{n} .27$ (arguing that independent directors of an SPE are under a fiduciary duty to the creditors of the SPE "to consider voting against" a voluntary bankruptcy of the SPE "in most situations").

30. See Steven L. Schwarcz, Credit Lyonnais Case Clarifies ABS [Asset-Based Securities] Issues in Bankruptcy, ASSET SALES REPORT, Oct. 12, 1992, at 1 (discussing the argument that directors of an SPE are obligated to the creditors of the SPE to vote against voluntary bankruptcy unless there is assurance that they will be paid).

31. Id. 
SPE from filing a petition while it is solvent. ${ }^{32}$ Or, the SPE may be owned and controlled by an independent third party rather than by the lessee.

In addition to restricting a voluntary filing, care is also taken to restrict the situations in which the creditors of the SPE may force it into bankruptcy. The most common approach appears to be to limit the activities of the SPE. The charter of the SPE can limit its trade creditors and the debt it can incur. Indeed, it is common for an SPE to be prevented from engaging in any business activity other than the transactions specified in a particular set of documents. To emphasize, the documents may make clear that the SPE is not to have an office, employees, or even to purchase office supplies. In the context of synthetic leases of real property, the SPE's charter may prohibit any transactions other than the designated acquisition or construction of property, the financing of the property in the short- or long-term debt markets, and the leasing of the property under terms specified in advance.

Even if there is no voluntary filing of bankruptcy by the SPE, and even if the SPE has no creditors other than the holders of its debt who have been pledged the rental receivable from the user, it is still possible that, under equitable principles, a court would consolidate the assets and liabilities of the lessee and the SPE. ${ }^{33}$ Consolidation is one of the principal topics addressed by FASB and is another way of approaching the lessee's relationship to the underlying assets and debt.

32. See SCHWARCZ, supra note 21 , at 21 (describing a "FINCO" or "two-tiered" structure); see also Special Report by the TriBar Opinion Committee, Opinions in the Bankruptcy Context: Rating Agency, Structured Financing and Chapter II Transactions, 46 BUS. LAW. 718 (1991).

33. See generally Cohn, supra note 19, at 929; SCHWARCZ, supra note 21, at 25 (stating that courts identify the following factors to decide whether to require substantive consolidation:

1. The degree of difficulty in segregating and ascertaining individual liabilities and assets;

2. The presence or absence of consolidated financial statements;

3. The commingling of assets and business functions;

4. The unity of ownership and interests between the corporate entities;

5. The guaranteeing by the parent of loans of the subsidiary; and

6. The transfer of assets without formal observance of corporate formalities).

Schwarcz concludes that it "would not appear likely that a court would substantively consolidate the assets and liabilities of an [SPE] and a bankrupt originator in a typical transaction." Id. at 26. His reasoning is that "[c]ourts have held that because substantive consolidation is an equitable remedy, it should not be used to harm innocent holders of securities of the company that is the target of consolidation." Id. at 25 . On the other hand, there are other, arguably more "innocent" creditors to be considered. Consider for a moment the creditors of a business who have bargained for debt covenants prohibiting the business from incurring further debt. Assume the business subsequently enters into a synthetic lease, which in substance is a mortgage but which the business only recognizes as debt when it chooses, for example, on its federal income tax return. The business's SPE is likely to issue debt under a prospectus or private placement memorandum that discloses that the transfer of the assets to the SPE might be considered a fraudulent transfer. In this scenario, the business's creditors seem more "innocent" than the SPE's creditors. They also are arguably the victims of a clever scheme to deprive them of the benefit of their protective covenants. 


\section{Financial AcCounting StandardS}

\section{A. Two Ways to Challenge the Transaction}

It is beyond the scope of this Article to consider all of the financial accounting standards applicable to structured finance and asset securitization. Nevertheless, it is important to consider key financial accounting standards that make synthetic lease transactions possible. There are two basic ways that financial accounting standards might interdict an attempt to use a lease to achieve off-balance sheet real estate financing. Under the first approach, the standards examine the lease provisions to determine whether the lease must be reported as a long-term liability of the tenant. Under the second approach, the standards consider a relationship between a tenant and an SPE to determine whether the tenant and the SPE must report via a consolidated financial retum. Under this second approach, although the lease is not directly recharacterized as an independent matter, the effect is the same because the debt of the SPE shows up on the tenant's newly consolidated balance sheet.

\section{B. Challenging the Lease Itself}

\section{FAS 13 and FAS 98}

The two principal Statements of Financial Accounting Standards (FAS) that address the characterization of real estate leases are FAS $13^{34}$ and FAS $98 .{ }^{35}$ FAS 13 is the broader of the two standards, because it applies to leasing transactions generally. ${ }^{36}$ FAS 98 , on the other hand, applies only to the specialized circumstances of sale-leasebacks. ${ }^{37}$ There is a critical distinction between FAS 13 and FAS 98 . FAS 98 is far more strict in requiring leases to be represented as debt on a tenant's balance sheet. ${ }^{38}$ Thus, in

34. See ACCOUNTING FOR LEASES, Statement of Financial Accounting Standards No. 13 (Financial Accounting Standards Bd. 1976) [hereinafter FAS 13].

35. See AcCounting for Leases: Sale-Leaseback Transactions Involving Real Estate, SalesTYPE LEASES OF REAL ESTATE, Definition OF THE LEASE TERM, INITIAL DiRect Costs of Direct FINANCING LEASES, Statement of Financial Accounting Standards No. 98 (Financial Accounting Standards Bd. 1988) [hereinafter FAS 98].

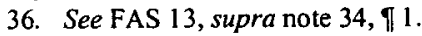

37. See FAS 98 , supra note $35, \$ 6$.

38. FAS 98 focuses on sale-leasebacks of real estate, including sale-leasebacks that include equipment. Most basically, FAS 98 prohibits sale-leaseback accounting unless the transaction qualifies as a true sale, which will be denied if the lessee has any continuing involvement other than a "normal leaseback" in which the sellerlessee intends to actively use the property during the lease. FAS 98 further states:

[S]ale-leaseback accounting shall be used by a seller-lessee only if a sale-leaseback transaction includes all of the following:

a. a normal leaseback;

b. payment terms and provisions that adequately demonstrate the buyer-lessor's initial and continuing investment in the property;

c. payment terms and provisions that transfer all of the other risks and rewards of ownership as demonstrated by the absence of any other continuing involvement by the seller-lessee. 
constructing a synthetic lease transaction to achieve the desired accounting result, lessees first seek to avoid application of FAS $98 .{ }^{39}$ In practical terms, this means that the lessor must acquire the asset from someone other than the lessee. ${ }^{40}$ Once application of FAS 98 is avoided, ${ }^{41}$ the lease is drafted to pass muster under FAS 13.

\section{The Four Tests of FAS 13 and Consequences of a Capital Lease}

In order to achieve off-balance sheet financing under FAS 13, the lease must be classified as an "operating" lease rather than as a "capital" lease. ${ }^{42}$ FAS 13 states that a lease is a capital lease if it meets any one of four criteria. If none of those criteria is met, the lease is treated as an operating lease. ${ }^{43}$

A lease is automatically classified as a capital lease if it meets one or more of the following criteria: (1) if the lease transfers ownership of the property to the lessee by the end of the lease term; $; 4$ (2) if the lease contains a bargain purchase option to purchase the leased property; ${ }^{45}(3)$ if the lease term is equal to seventy-five percent or more of the estimated economic life of the leased property; 46 (4) if the present value, at the beginning of the lease term, of the minimum lease payments equals or exceeds ninety percent of the excess of the fair value of the leased property to the lessor at the inception of the lease

FAS 98 , supra note $35, \pi 7(\mathrm{c})$. Continuing involvement includes any option to repurchase the property in the absence of a bonafide third-party offer to purchase. FAS 98, supra note 35, 111 (a). In contrast, FAS 13 views an option to repurchase as fatal only if it is at a bargain price. See FAS 13 , supra note 34 , 77 .

39. FAS 98 only applies to real estate, property improvements, and integral equipment. See FAS 98, supra note 35,16 . Property improvements and integral equipment are defined as "any physical structure or equipment attached to the real estate ... that cannot be removed and used separately without incurring significant cost." Id. If 6 n.2. Assets that can be moved "[without] incurring significant cost" are not subject to FAS 98. Id.

40. See Holmes, supra note 24 , at $17,20$.

Generally, SFAS 98 provides that the seller in such a transaction is precluded from recognizing a sale if it retains options to purchase or provides guarantees or other provisions that constitute "continuing involvement" with the property. Since such provisions are integral to the synthetic lease structure, the lessee must avoid obtaining title to the leased property (including the land).

A direct purchase on the part of the lessor/SPE will avoid this pitfall. However, the lessee should avoid guarantees or commitments during the construction period that would make it, in substance, the owner of the project.

Id. at 20 .

41. The Emerging Issues Task Force has stated that in build-to-suit lease transactions, "[a] lessee who commences construction activities would recognize the asset (construction in progress) on its balance sheet, and any subsequent lease arrangement would be within the scope of [FAS] 98." EITF 96-21: IMPLEMENTATION ISSUES IN ACCOUNTING FOR LEASING TRANSACTIONS INVOLVING SPECIAL-PURPOSE ENTITIES, EITF Abstracts Issue No. 96-21 (Financial Accounting Standards Bd., Emerging Issues Task Force 1996) [hereinafter EITF 9621 ].

42. See FAS 13, supra note 34, ๆ 7.

43. Id.

44. See FAS 98, supra note 35 , ๆ 22(a) (amending the definition of "lease term" in FAS 13, I 5(f)).

45. See FAS 13 , supra note 34 , ๆ $5(\mathrm{~d})$.

46. See id. If $5(\mathrm{~g})$ (defining "estimated economic life of leased property"). This criterion is not used to classify the lease if the beginning of the lease term falls within the last $25 \%$ of the total estimated economic life of the leased property. Id. $\{7(\mathrm{c})$. 
over any related investment tax credit retained by the lessor. ${ }^{47}$ Stated somewhat differently, if a lease flunks any one of these four tests, the lessee will be required to report it as a capital lease on its books. ${ }^{48}$

Treating the lease as a capital lease means several things. First, the lessee records the capital lease as an asset and as an obligation at an amount equal to the present value at the beginning of the lease term of the minimum payments over the lease term. ${ }^{49}$ If both land and buildings are involved, they must be separately capitalized in proportion to their fair values at the inception of the lease. ${ }^{50}$ Second, the capitalized building asset must be amortized. ${ }^{51}$ Third, each minimum lease payment must be allocated between a reduction of obligation and interest payment. ${ }^{52}$ Finally, "a termination of a capital lease must be accounted for by removing the asset and obligation" and recognizing gain or loss for the difference. ${ }^{53}$ On the other hand, if none of the four characteristics is present, and the lease is treated as an operating lease, the asset goes on the lessor's balance sheet ${ }^{54}$ and the lessee ordinarily charges rent to expense over the lease term as it becomes payable. ${ }^{55}$

\section{The Core "Concept" of FAS 13}

The four criteria of FAS 13 are said to be derived from the "concept" that a lease must be capitalized if it transfers substantially all the benefits and risks of ownership to the tenant, even if it is not equivalent in substance to a purchase:

[A] lease that transfers substantially all of the benefits and risks incident to the ownership of property should be accounted for as the acquisition of an asset and the incurrence of an obligation by the lessee and as a sale or financing by the lessor. All other leases should be accounted for as operating leases. In a

47. Consider, for example, a lease provision that anticipates a sale of the building at the end of the lease. If the sales proceeds are insufficient to retum the lessor's investment and that of its creditors, the lessee cannot pledge in advance to make up the full amount without running afoul of the $90 \%$ test of FAS 13:

In the event the sales proceeds are insufficient to recover the lessor's net investment, [the lessee] would be required to make a contingent rental payment to the lessor in an amount equal to the shortfall, but subject to an overall cap such that the amount of the contingent rent payment, when added to the scheduled monthly lease payments, does not exceed $89.9 \%$ of the original cost of the asset.

Holmes, supra note 24, at 19.

48. FAS 13 provides special rules that vary the application of the basic tests when a lease involves real

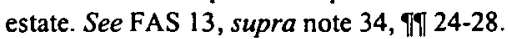

49. Id. ๆ 10. "However, if the amount so determined exceeds the fair value of the leased property at the inception of the lease, the amount recorded as the asset and obligation shall be the fair value." Id.

50. Id. $\ 26$.

51. Id. ๆ 11. Land capitalized under a lease that meets the first two of the four criteria will normally not be amortized. FAS 13, supra note 34 . \26(a)(I).

52. Id. ๆ 12.

53. Id. ๆ 14(c).

54. Id. ๆ 19(a).

55. Id. T 15, at n.30. While FAS 13 does not require property subject to an operating lease to appear as an asset on the balance sheet, it does require disclosure of operating lease obligations by way of a footnote to the balance sheet. See FAS 13, supra note 34, If 16. For operating leases having non-cancelable lease terms longer than one year from the date of the current balance sheet, the footnote disclosure must include future minimum rental payments in the aggregate and for each of the five succeeding fiscal years. See id. 1 16(b)(i). 
lease that transfers substantially all of the benefits and risks of ownership, the economic effect on the parties is similar, in many respects, to that of an installment purchase. This is not to say, however, that such transactions are necessarily "in substance purchases" as that term is used in previous authoritative literature. 56

The drafters of FAS 13 thought that its principal contribution was to extend the "substantially all of the benefits and risks" analysis to lessees and thereby require lessees to report according to the same principles that had come to be applied to lessors. ${ }^{57}$ Interestingly, the Board specifically declined the opportunity to harmonize the financial accounting standards with federal income tax law.

\section{FAS 13 and Tax Consequences}

FAS 13 addressed the interplay between accounting treatment and tax treatment. With respect to sale-leasebacks in particular, the Board noted that most are entered into "as a means of financing, for tax reasons, or both" and that the terms of the sale and the terms of the lease are usually negotiated as a package.

Because of this interdependence of terms no means could be identified for separating the sale and the leaseback that would be both practicable and objective. For that reason, the Board concluded that the present general requirement that gains and losses on sale leaseback transactions be deferred and amortized should be retained. An exception to that requirement arises when the fair value of the property at the time of the transaction is less than its undepreciated cost. In that case, the Board decided that the loss should be

\section{Id. ๆ 60 .}

57. Id. ๆ 61 :

The transfer of substantially all the benefits and risks of ownership is the concept embodied in previous practice in lessors' accounting ... However, a different concept has existed in the authoritative literature for lessees' accounting. ... [Earlier authority] required capitalization of those leases that are "clearly in substance installment purchases of property," which it essentially defined as those leases whose terms "result in the creation of a material equity in the property." Because of this divergence in both concept and criteria, a particular leasing transaction might be recorded as a sale or as a financing by the lessor and as an operating lease by the lessee.

See also id. ๆ 69. The Board explained its reason for rejecting the argument that the only leases that should be capitalized are those that are "in substance installment purchases": "Taken literally, the concept would apply only to those leases that automatically transfer ownership. All other leases contain characteristics not found in installment purchases, such as the reversion of the property to the lessor at the termination of the lease." FAS 13 , supra note 34,969 . Some members of the Board who supported FAS 13 held

the view that, regardless of whether substantially all the benefits and risks of ownership are transferred, a lease, in transferring for its term the right to use property, gives rise to the acquisition of an asset and the incurrence of an obligation by the lessee which should be reflected in his financial statements. 
recognized up to the amount of the difference between the undepreciated cost and fair value. 58

Nevertheless, and more broadly, when it adopted FAS 13, the Board rejected as a criterion the fact that a lessee treats the lease as a purchase for federal income tax purposes. 59 The Board noted that there are "many instances in which tax and financial accounting treatments diverge, and the question of a possible need for conformity between them is beyond the scope of this Statement." 60 The current use of synthetic lease transactions suggests that this is an appropriate time for the Board to reconsider this decision.

In a typical synthetic lease transaction, the lessor and lessee agree in advance that the lessee, not the lessor, will report depreciation deductions for federal income tax purposes. As we shall see, this means that the lessor and lessee agree ex ante that the lessee has the great bulk of the benefits and burdens of ownership. If both lessor and lessee are taking this position for federal income tax purposes, which essentially means that the lessee is more properly characterized as the owner and debtor than the lessor, the Board should require disclosure.

In making this requirement, the Board would not be basing reporting for financial accounting purposes on a tax rule that frequently changes. First, federal income tax analysis has for decades been based on a benefits and burdens analysis and is not likely to change. ${ }^{61}$ Second, the requirement should not be viewed as basing FAS treatment on federal income tax treatment (which may not be finally determined for years). Rather, the proposed disclosure is of a contractual understanding rather than of a speculation about a legal outcome. The Board should simply require the lessee to disclose to lenders and investors the contractual agreement with the SPE that the lessee rather than the lessor is to claim both ownership and debt for federal income tax purposes. Stated somewhat differently, the typical publicly-held lessee should disclose on the financial statements it submits to the SEC the contractual understanding about what it will report to the Service.

\section{Requiring Consolidation of Lessee and Special Purpose Entity}

\section{Introduction}

To recapitulate, if no sale-leaseback is involved, such that FAS 98 is inapplicable, it currently is fairly easy for a business that wants off-balance sheet financing to structure a lease that will not be classified as a capital lease within the meaning of FAS 13. The lease term and contingent rental payments can be adjusted to satisfy the classification criteria. However, if the lessor is not an independent business or appears to be acting as an agent of the lessee for purposes of obtaining financing, ${ }^{62}$ classifying the lease as an operating lease does not necessarily mean that it remains off-balance sheet. In certain situations, the

58. Id. $\mid 107$. Although FAS 28 modified FAS 13 with respect to sale-leasebacks, the major change with respect to sale-leasebacks of real property was announced in FAS 98 , which requires capitalization of many more sale-leasebacks. See supra Part III.B.1.

59. FAS 13 , supra note $34, \Upsilon 78$.

60. Id.

61. See infra Part V.

62. This is sometimes discussed in terms of the financing corporation serving as a "friendly" lessor. 
Board requires consolidation of the financial statements of a lessee and an SPE, bringing both the asset and its encumbrance onto the books of the lessee.

Capitalization based on the lessor's lack of substance was put on the back burner when the Board adopted FAS 13. The Board rejected as a criterion of lease characterization that the lessor is without independent substance:

The Board considered the argument ... that, if the lessor has no economic substance, the lessor serves merely as a conduit in that the lender looks to the lessee for payment and thus, it is asserted, the lessee is, in fact, the real debtor and purchaser.... The Board finds unpersuasive the argument that the lessee's accounting for a leasing transaction should be determined by the economic condition of an unrelated lessor. If ... an unrelated lessor lacks independent economic substance... it probably means that someone else, presumably the lender, is in substance the lessor, but this circumstance, per se, should not alter the lessee's accounting. ${ }^{63}$

Concern over unrelated lessors without independent economic substance finally got moved to a front burner when the Emerging Issues Task Force addressed what it labeled Issue Number 90-15.

EITF $90-15^{64}$ responds to concern over the gap in treatment between FAS 13 and FAS 98. The Task Force perceived that SPEs were being used to avoid FAS 98 while achieving "substantive," though not "formal," sale-leasebacks. EITF 90-15 established three factors that, if present, require consolidation of the financial statements of lessor and lessee. Six years later, as interest in the use of synthetic leases increased, EITF 96$21^{65}$ clarified the application of the three factors.

\section{EITF $90-15$ and EITF $96-21$}

EITF 90-15 defines circumstances in which an SPE will be consolidated with a lessee for financial statement purposes because of the SPE's "lack of economic substance." 66 A lessee is required to consolidate an SPE lessor when all of the following conditions exist:

1. Substantially all of the activities of the SPE involve assets that are to be leased to a single lessee; 67

2. The expected substantive residual risks and substantially all of the residual rewards of the leased assets and the obligations imposed by the underlying debt of the SPE reside, directly or indirectly, with the lessee. ${ }^{68}$

63. FAS 13 , supra note $34,182$.

64. See EITF 90-15: IMPACT OF NONSUBSTANTIVE LeSSORS, RESidual Value GuaranteEs, AND Other Provisions IN LEASING TRANSACtions, EITF Abstracts Issue No. 90-15 (Financial Accounting Standards Bd., Emerging Issues Task Force 1990) [hereinafter EITF 90-15].

65. See EITF 96-21: IMPLEMENTATION ISSUES IN ACCOUNTING FOR LEASING TRANSACTIONS INVOLVING SPECIAL-PURPOSE ENTITIES, EITF Abstracts Issue No. 96-21 (Financial Accounting Standards Bd., Emerging Issues Task Force 1996) [hereinafter EITF 96-21].

66. See Nesvold, supra note 13 , at 105 .

67. Id. at 106 . 
3. The owners of record of the SPE have not made an initial substantive residual equity capital investment that is at risk during the entire term of the lease. ${ }^{69}$

If these conditions all exist, the assets, liabilities, results of operations, and cash flows of the SPE must be consolidated in the lessee's financial statements. Stated somewhat differently, the leases must be capitalized by the lessee. EITF $90-15$ is not as onerous as it first appears because it requires consolidation only if all three conditions are met. ${ }^{70}$

The first condition is met when substantially all of the activities of the SPE involve assets that are to be leased to a single lessee. ${ }^{71}$ However, simply ensuring that the SPE leases assets to more than one lessee does not ensure that the condition will be avoided..$^{72}$ EITF 96-21 makes clear that this is, at least to some extent, a substantive, and not merely a formal requirement. It states, for example, that "the use of nonrecourse debt with no cross-collateral provisions effectively segregates the cash flows and assets associated with the two leases and, therefore, in substance, creates two SPEs."73 EITF 96-21 continues, stating:

For either lessee to be in a position of not satisfying condition 1 of Issue 90-15, the assets of the SPE would need to be commingled such that in the event of default, both lenders to the SPE would have equal rights ... to the cash flows and assets related to both leases of the SPE. ${ }^{74}$

68. Id. at 106. EITF 90-15 states that the residual risks and substantially all the residual awards of the asset and the obligation of the SPE's debt may reside with the lessee through such means as:

a. The lease agreement;

b. A residual value guarantee through, for example, the assumption of first dollar of loss provisions;

c. A guarantee of the SPE's debt;

d. An option granting the lessee a right to (1) purchase the leased asset at a fixed price or at a defined price other than fair value determined at the date of exercise or (2) receive any of the lessor's sales proceeds in excess of a stipulated amount.

EITF 90-15, supra note 64.

69. Nesvold, supra note 13 , at 106.

70. For a recent proposal for reform of the financial accounting treatment of synthetic leases, see Nesvold, supra note 13, 112-13:

The optimal result would likely follow were the FASB to modify EITF 90-15 in either of two respects. First, the FASB might consider requiring the SPE-owner of record to invest more than a three percent equity stake in order for a synthetic lease to qualify for off-balance sheet treatment. ...

Second, the FASB might consider adding a fourth prong to EITF 90-15: that the lesseecorporation must consolidate the lessor-SPE where the synthetic lease contains an option to purchase the underlying property either at future fair market value or at the lessor-SPE's unamortized principal balance on the remainder of the lease.

71. See EITF $96-21$, supra note 65 .

72. Id.

73. Id.

74. Id. 
Most commonly, the very nature of a synthetic lease transaction, in which a user finances on the strength of its own credit and segregates and pledges a group of choice assets, means that, in substance, there is only one lessee and that the first condition will be met.

The second condition is met when the expected substantive residual risks, substantially all the residual rewards of the leased assets, and the obligations imposed by the underlying debt of the SPE reside directly or indirectly with the lessee. Risks, rewards, and obligations can be put on the lessee by terms of the lease, a residual value guarantee, a guarantee of the SPE's debt, an option granting the lessee a right to purchase at a fixed price or at a defined price other than fair value at the date of exercise, or a right of the lessee to receive any of the lessor's sales proceeds in excess of a stipulated amount. EITF 90-15 states that to determine if a "registrant has substantive residual risks and rewards of the leased asset ... the SEC staff would review a transaction to determine if the lessee has ... elements of management or control." 75 Elements of management or control include "a nonsubstantive lessor without equity at risk, a lessee who has the ability to realize all appreciation and bears substantial risk of depreciation, and a lessee who acts as the construction agent and selling agent and who is at more than nominal risk." 76 As with the first condition, the second condition is typically present because synthetic leases, by their very nature, involve tenants who are the moving force. They are typically as insistent upon retaining practical control as they are in renouncing formal ownership.

The third condition is met if the owners of the SPE have not made an initial substantive residual equity capital investment that is at risk during the entire term of the lease. This is the condition that is typically avoided in the modern synthetic lease transaction. ${ }^{77}$ It is avoided by having the SPE provide and retain an equity. The SPE owners of record must make a capital investment "comparable to that expected for a substantive business involved in similar leasing transactions with similar risks and rewards."78 The EITF working group indicated that three percent is the minimum acceptable investment, ${ }^{79}$ although the SEC staff believed that a greater investment may be required, depending on the circumstances of the lease. ${ }^{80}$ Once the initial investment is

75. See EITF 90-15, supra note 64.

76. Id.

77. See James Blythe Hodge, The Synthetic Lease: Off-Balance Sheet Financing of the Acquisition of Real Property, 433 PLI/REAL 657, 667 (Order No. N0-0013) (1998); see also Evelyn Giacco, Synthetic Lease Transactions and "Off-Balance Sheet" Financing, 424 PLI/REAL 563, 573 (Order No. N4-4608) (1997); Nancy R. Little, Unraveling the Synthetic Lease, PROB. \& PROP. , Jan.-Feb. 1997, at 22, 24.

78. EITF 90-15, supra note 64, at Response to Question No. 3.

79. Holmes, supra note 24, at 20:

Since the first two tests speak directly to the structural fundamentals of the synthetic lease arrangement, most practitioners focus on the amount invested and "at risk" by the owner(s) of record of the SPE based on the third requirement outlined. While definitive guidance is lacking in this area, practical interpretation of this rule commonly provides for a $3 \%$ minimum initial equity investment. To the extent this amount is invested by the owner(s) of record of the SPE based on the criteria outlined in EITF 90-15, the lessee's off-balance sheet treatment can be protected.

80. Id. 
made, it must remain at risk for the entire term of the lease to continue to insure criterion three remains unmet. 81

\section{SPEs and Professional Test Flunkers}

To enable corporate users to avoid lease reclassification and consolidation, a specialized financial services sector has sprung up to create and maintain financing transactions with an SPE as the centerpiece. The SPE must not be owned by the tenant and must be given sufficient risks and rewards to forestall reclassification of the lease and consolidation:

There are many players ... providing synthetic real estate funding services. ... Generally, these companies arrange all of the financing through the term of the lease, negotiate with the banks for credit support facility or provide the credit support facility, service the commercial paper, administer the program, and take a portion of the residual value risk in order to satisfy the SFAS 13 requirements. The sources are compensated through an upfront structuring fee and $a$ fee incorporated in the lease rate for the residual value risk as well as for ongoing administrative services. ${ }^{82}$

In short, the principal route to achieving the proper financial accounting treatment appears to be to shift a portion of the residual risk to the SPE. 83

In many cases, the true nature of the relationship between the SPE and the tenant may be made much more readily apparent in the offering literature or correspondence of the professionals offering to corporate financiers their expertise in creating and maintaining leases that avoid reclassification and SPEs that avoid consolidation. This background documentation - rather than the leases, note purchase agreements, options or other documents of the financing transaction that is ultimately consummated-may make it clear that the SPE is a "friendly" lessor that will, in effect, hold title for the benefit of the tenant. From the outset, it will be understood that the tenant will have and retain great control over the property, including perhaps the right to substitute properties. Furthermore, the tenant's offers, even if labeled "rejectable," will be treated as binding options to purchase and, most assuredly, the tenant, not the landlord, will be the only one to report depreciation deductions for state and federal income tax purposes.

\section{State Mortgage Law of Substance over Form}

The transfer of title to secure repayment of a loan has a long history. ${ }^{84}$ Nevertheless, the development of Anglo-American mortgage law can be summarized briefly. At early common law, lenders asked borrowers to convey property to secure the repayment of

81. Id.

82. Howard A. Zuckerman, Lenders Get Creative with New Capital Structure: Synthetic Real Estate Funding, in CAPITAL SOURCES FOR REAL EST., Dec. 1995, at 31 (emphasis added).

83. See Holmes, supra note 24 , at 20 (noting in a typical illustration that the only difference in substance from a loan secured by the leased assets is "a partial shift of the residual risk to the synthetic lessor in the event the building retains only a substantially diminished residual value").

84. For an excellent one-volume discussion on the law of mortgages and mortgage substitutes, see GRANT S. Nelson \& Dale A. Whitman, Real Estate FinanCe LaW (3d ed. 1994). 
debt. The conveyance was in fee simple subject to a defeasance clause-typically a fee simple on condition subsequent. ${ }^{85}$ In short, the conveyance ran from borrower to lender and said that if, and only if, the borrower made full repayment of principal and interest exactly on time, the borrower could reenter and extinguish the lender's estate. ${ }^{86}$ Borrowers defaulted and asked courts of equity to grant them relief from forfeitures. ${ }^{87}$

Defaulting borrowers sought to protect two interests. First, they sought the right to pay off the loan and hence redeem the property from a default. As a practical matter, given the presence of acceleration clauses that permit a lender to call due the entire outstanding amount of a loan upon default, this is the right of a borrower to pay off the loan, with interest and costs. However, this right is of little value to a borrower who is unable to pay off the loan. A second right was therefore recognized, the right to recover the value of the property remaining after the property is sold to satisfy the lender's interest in recovering principal, interest, and costs. ${ }^{88}$ In short, the transfer of title came to be treated as simply a means of securing the lender's only legitimate objective: to recover principal, interest, and any extra costs incurred on account of a default.

The borrower's right to redeem by paying late was granted so regularly it came to be granted as a matter of right and not merely as a matter of equitable discretion. 89 By taking out a secured loan, the borrower is said to have an "equity of redemption," which came to be regarded as an estate in land..$^{90}$ As with other basic estates in land, it is under the protection of the courts and will not be taken away lightly. For example, just as an estate in fee simple is not taken away simply because it is in a parcel of land that is not being used, so, too, an equity of redemption is not taken away simply because its owner is slow to invoke it. The secured lender must act to extinguish the equity.

Lenders, on the other hand, needed a process that would allow them to close the books on a secured loan in default. To respond to the needs of both borrowers and lenders, a process of "foreclosure" was developed. ${ }^{91}$ A decree of foreclosure ends the borrower's right to assert an equity of redemption. The borrower is told: redeem yourself from your default by paying late, or be forever foreclosed from ever again asserting any right, title, or interest in or to the property. This much alone would constitute a strict foreclosure. For centuries, our law has gone the further step of returning to the borrower any remaining value in the property after the lender has recovered principal, interest, and costs. ${ }^{92}$ This is accomplished by a foreclosure by sale: if the borrower is not able to pay late or chooses not to pay late, the property pledged as security is sold and any surplus after satisfying the lender's principal, interest, and costs is paid to the borrower. In most states, the foreclosure sale must be conducted through a court. ${ }^{93}$ In others, nonjudicial

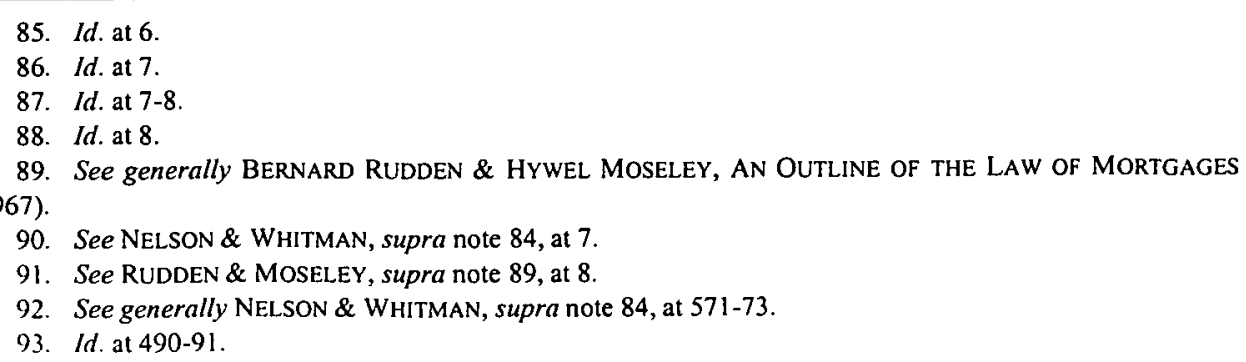


foreclosure under a power of sale clause in a deed of trust or in a mortgage is enforceable. ${ }^{94}$

Lenders are not permitted to require borrowers to waive the equity of redemption as part of taking out a loan. A contemporaneous agreement waiving the equity of redemption is simply unenforceable. Mortgage law sometimes states the rule in terms of the impermissibility of "clogging" of the mortgagor's equity of redemption. ${ }^{95}$ This is true whether the attempted waiver is explicit or implicit. For example, the conveyance of a fee simple absolute, unconditional on its face, can be established as a mortgage if it is shown to have been made as part of a secured loan. Similarly, a purchase money mortgage can be found even if a deed purports to convey unqualified title from a seller to a purported lender.

For centuries, lenders have tried to avoid the foreclosure process by characterizing a borrower's possession as that of a lessee rather than as that of a mortgagor in possession. In some cases, sale-leasebacks have been involved, whereas in others, the lenders have acquired title directly from third parties. ${ }^{96}$ In both types of cases, the nominal lessee must establish that the conveyance to the alleged lender was intended to secure a promise to repay. In a typical lease case, the search is for the promise to repay. It can be found, at one extreme, in a "put," a right of the alleged lender to require the lessee to purchase the property. ${ }^{97}$ Or it can be found in the form of a favorable option to purchase, which the lessee is economically compelled to exercise. Finally, it can be found even if there is nothing stating a right to a reconveyance, if the transaction otherwise makes no sense. For example, it is easy for courts to find that a conveyance that is "absolute" or unqualified on its face, for an amount well below market value, was intended to secure the repayment of a loan..$^{98}$ If a lease is shown to have been intended as a mortgage, the lessee has an equity of redemption that can only be extinguished by the appropriate foreclosure process, and not under the more summary remedies of landlord-tenant law.

\footnotetext{
94. Id. at 512-13.
}

95. Id. at 32-33:

Following their original intervention equity courts developed the doctrine prohibiting the clogging of the mortgagor's equity of redemption. Under this doctrine, even though the mortgage is in default, normally no agreement contained in the mortgage, or contemporaneous with it, can cut off a recalcitrant mortgagor's equity of redemption without the resort to foreclosure by the mortgagee. (emphasis added).

96. See Talbot v. Gadia, 267 P.2d 436, 440 (Cal. Ct. App. 1954):

When a conveyance is executed from the vendor directly to the lender, to secure a loan of the purchase money made by him to the purchaser, the legal title is held not only for the lender as security, but also in trust for the borrower for the purpose of finally having title go to him. The grantee thus holds a double relationship to the purchaser, being a trustee of the legal title and mortgagee for the money advanced for its purchase. (citations omitted).

See also Wilcox v. Salomone, 258 P.2d 845, 849 (Cal. Ct. App. 1953):

Although this is a three-party rather than a two-party transaction, wherein the one who takes title to the property holds it as trustee for the party to whom he loaned the purchase money, and also holds a lien as mortgagee for repayment of the loan, the usual rules applying to a deed absolutemortgage case apply here.

97. See Golden State Lanes v. Fox, 42 Cal. Rptr. 568 (Ct. App. 1965).

98. See NELSON \& WHITMAN, supra note 84 , at 52. 
State common law is often supplemented by a state statute affirming that any instrument that serves as a mortgage must be treated as a mortgage, regardless of form. In the language of an earlier time, any interest "in the shape of a mortgage" can only be foreclosed "in like manner as a mortgage." 99 Such statutes typically provide that the statute cannot be relied on to the detriment of a good faith purchaser for value and without notice. ${ }^{100}$ The statutes are vigorously enforced because of the historic solicitousness courts have for borrowers and after centuries of experience with instruments and arrangements that are designed to keep foreclosures from judicial supervision. ${ }^{101}$

Neither the parole evidence rule nor the statute of frauds bars attempts to introduce evidence to establish that an instrument in some other form was intended as a mortgage. ${ }^{102}$ At bottom, the quest is for a promise to repay coupled with a pledge of property to secure repayment. Factors that are considered include an attempt to secure debt financing, the relationship of the consideration transferred to the value of the property, the intent of the transferor to retain possession and control of the property, provision for a reconveyance of the property to the transferor at the termination of a lease or otherwise, the existence of a favorable repurchase option, improvement of the property beyond what would normally be done by a tenant, and the assumption by someone other than the nominal owner of a wide range of benefits and burdens of ownership. ${ }^{103}$

\section{FEDERAL InCOME TAX LAW OF SUBSTANCE OVER Form}

\section{A. Introduction}

Just as state mortgage law has long disregarded form to recognize the substance of a loan, so too has the federal income tax law. Indeed, judicial opinions about tax law almost boastfully declare that substance controls form or the corollary that economically identical transactions shall be taxed identically absent, of course, the impurifying intervention of Congress. Although courts have frequently stated that the Service will be given more latitude to disregard the form of a transaction than the taxpayer who chose

99. An example of a more modem statute is FLA. STAT. ch. 697.01 (1999), entitled "Instruments Deemed Mortgages," which states:

All conveyances... or other instruments... conveying or selling property... for the purpose ... of securing the payment of money, whether such instrument be from the debtor to the creditor or from the debtor to some third person in trust for the creditor, shall be deemed and held mortgages, and shall be subject to the same rules of foreclosure and to the same regulations, restraints and forms as are prescribed in relation to mortgages.

See also CAL. CiV. CODE $§ 2924$ (West 1999) and N.Y. REAL PROP. $\$ 320$ (McKinney 1989).

100. See, e.g., FLA. STAT. ch. 697.01(2) (1999) ("[N]o such conveyance shall be deemed or held to be a mortgage, as against a bona fide purchaser or mortgagee, for value without notice, holding under the grantee."); see also Moeller v. Lien, 30 Cal. Rptr. $2 \mathrm{~d} 777$ (Ct. App. 1994).

101. See, e.g., Davis v. Stewart, 127 P.2d 1014 (Cal. Ct. App. 1942); Thomas v. Thomas, 96 So. 2d 771

(Fla. 1957); In re Nolta's Estate, 56 N.Y.S.2d 818 (Sup. Ct. 1945).

102. See NELSON \& WHITMAN, supra note 84 , at $48-50$.

103. See In re Wingspread, 116 B.R. 915 (Bankr. S.D.N.Y. 1990). See generally Thomas R. Fileti, Real Estate Off-Balance Sheet Financing (Synthetic Leasing), 418 PLI/REAL 1021 (Order No. N4-4603) (1997). 
it, ${ }^{104}$ both government and taxpayer have benefited from the opportunity to insist that substance trumps form.

An examination of key case law on whether a depreciable interest in real property is properly claimed by a lessor or by a lessee leads to three basic conclusions. First, the federal income tax case law, much like FAS 13, adopts a "benefits and burdens" analysis. ${ }^{105}$ Second, the benefits and burdens analysis supporting the claims of lessees in synthetic lease transactions reflects good tax policy because it prevents taxpayers from "stripping" and assigning away depreciation deductions to mortgage brokers or others seeking to traffic in tax losses. Third, the maturity and stability of the benefits and burdens analysis suggest that FASB should require capitalization when lessor and lessee, ex ante, agree that the lessee, and not the lessor, will report a depreciable interest with debt in basis.

\section{B. Four Recent Cases}

At least since Helvering v. F. \& R. Lazarus \& Co., 106 it has been clear that a lessee may be permitted to disregard the form of a lease if it is, in substance, a mortgage. The Supreme Court in Lazarus stated that "[w]here it has been shown that a lessee using property in a trade or business must incur the loss resulting from depreciation of the capital he has invested, the lessee has been held entitled to the statutory [depreciation] deduction." 107 Four opinions subsequent to Lazarus illustrate the evolution of judicial thinking concerning the allocability of depreciation deductions. First is the Tax Court's opinion in Bolger v. Commissioner, ${ }^{108}$ which involved a successful taxpayer attempt to

104. See, e.g., Highland Farms, Inc. v. Commissioner, 106 T.C. 237 (1996). In ASA Investerings Partnership v. Commissioner, 76 T.C.M. (CCH) 325 (1998), the court disregarded the form of a transaction when one party, like the typical SPE in a synthetic lease transaction, "was a compliant and accommodating party ... chosen for the venture because it was willing to serve at [the other's] direction."

105. A benefits and burdens analysis is also applied under related provisions of state tax law. For example, a taxpayer faced with a state tax on "leasing" may be able to argue that the form of a lease should be disregarded because it is, in substance, a mortgage. See Bridgestone/Firestone, Inc. v. Dep't of Revenue, No. 92-2483, 15 FALR 4874 (Dep't Admin. H. 1993). In Hialeah, Inc. v. Dade County, 490 So. 2 d 998 (Fla. Dist. Ct. App. 1986), the court permitted a county to disregard the form of a sale-leaseback transaction and tax a "lessee" as the beneficial owner of the underlying real property. In form, the City of Hialeah was the owner. It issued notes secured by the revenue from the leases. The court concluded that title was in the city merely to secure the repayment of money and that the burdens and benefits of ownership were in the lessee, Hialeah, Inc.:

The lease payments due from Hialeah, Inc. are equivalent to the principal and interest which the city owes on its mortgage loans from the banks. Hialeah, Inc. pays the banks directly and makes no payments to the City of Hialeah. Hialeah, Inc. is obligated to pay all taxes, insurance and expenses relative to the subject property. The city makes no payments whatsoever. Hialeah, Inc.'s obligation is absolute. It is required to make lease payments even if it is evicted from the property, if the leased premises are destroyed, or if the property is taken by eminent domain. The city is not permitted to convey title to the property except subject to the lease. Any condemnation award must first be used to repay any outstanding debt; any excess then goes to Hialeah, Inc.

Id. at 998-99. A successful recharacterization of a lease may implicate other taxes, such as a documentary stamp tax on mortgages. See Fla. Dep't Rev., Tech. Assistance Adv. 97A-001 (Jan. 8, 1996); Fla. Dep't Rev., Tech. Assistance Adv. 96(M)-002 (June 21, 1996).

106. 308 U.S. 252 (1939).

107. Id. at 254 .

108. 59 T.C. 760 (1973). 
assign depreciation deductions to an SPE owned by the orchestrator of the financing transaction. Second is the Third Circuit's opinion in Sun Oil Co. v. Commissioner, ${ }^{109}$ which involved a successful attempt by the Service to recharacterize a lessee as the substantive owner of property. Third is the Supreme Court's opinion in Frank Lyon Co. $v$ United States, ${ }^{110}$ which reflects the latest Supreme Court pronouncement on the allocability of the depreciation deduction between real estate lessor and lessee. Fourth is the Tax Court's opinion in Hilton v. Commissioner, ${ }^{111}$ which repudiated Bolger and applied Frank Lyon Co. in a way that limits the ability of taxpayers to allocate depreciation deductions to SPEs with nominal equity.

\section{Bolger's Building: Nobody Said It Was a Mortgage}

Bolger v. Commissioner ${ }^{112}$ was one of the great court victories for the tax shelter industry. The Service challenged ten transactions of David Bolger, a real estate investor and financier, that had the same basic pattern. Bolger would form a financing corporation with an initial capitalization of $\$ 1,000 .^{113}$ The financing corporation purchased a building that a manufacturing or commercial user wanted to lease-on occasion the seller and the user were the same. ${ }^{114}$ Then, typically on the same day, all of the following would take place: the seller conveyed the property to the financing corporation, the financing corporation entered into a lease with the user, the financing corporation sold its own negotiable interest-bearing notes in an amount equal to the purchase price to an institutional lender (or lenders) pursuant to a note purchase agreement that secured the notes by a first mortgage (or deed of trust) and by an assignment of the lease. ${ }^{115}$ The mortgage notes were to be paid over a period no longer than the primary term of the lease and the financing corporation paid all the lender's expenses, including legal fees. ${ }^{116}$ The financing corporation transferred title to its shareholders, typically Bolger himself and other individuals he selected, who took subject to the mortgage. ${ }^{117}$ Bolger and the other transferees claimed a cost basis in the building that included the amount of the mortgage notes and reported depreciation deductions accordingly. ${ }^{118}$ The Service denied Bolger's claim to depreciation deductions, arguing that the depreciable interest remained in the financing corporation. ${ }^{119}$ The service did not argue that the tenant-users were the true owners.

The financing corporation was typical of many SPEs in synthetic lease transactions. It promised to maintain its existence, and it also promised to refrain from all business activity except that which arose out of the ownership and leasing of the property. ${ }^{120}$

109. 562 F.2d 258 (3d Cir. 1977)

110. 435 U.S. 561 (1978), rev'g 536 F.2d 746 (8th Cir. 1976).

111. 74 T.C. 305 (1980), aff'd, 671 F.2d 316 (9th Cir. 1982).

112. 59 T.C. 760 (1973).

113. Bolger, 59 T.C. at 761 .

114. Id.

115. Id. at $761-62$

116. Id. at 761 .

117. Id.

118. Bolger, 59 T.C. at 765.

119. Id.

120. Id. 
Payments by the lessee were made directly to the mortgagee or trustee to service the financing corporation's secured notes, with any small excess paid to the financing corporation. $^{121}$

The initial documents anticipated that the financing corporation would transfer title to a grantee who would take subject to, but not assume, the obligations of the financing corporation. ${ }^{122}$ The grantee was required to compel the financing corporation to remain in existence, to prevent it from engaging in any other business, to cause it to maintain its books and keep them available for inspection by the mortgagee, and to prevent its merger or consolidation with any other corporation. ${ }^{23}$

The leases were for a primary term at least equal to the term of the mortgage note, occasionally longer. ${ }^{124}$ The leases were all triple-net leases that unconditionally required the lessee to pay rent, even if the buildings were destroyed. ${ }^{125}$ In the event of destruction, the lessee had a right to purchase the property for a price set according to a schedule that approximated the amount necessary to prepay the note. ${ }^{126}$ The lessee also agreed to indemnify the lessor against any liability resulting from any occurrence on the premises or because of work done on the premises by the lessee. ${ }^{127}$ The lessee was permitted to sublease or assign, provided the transferee promise to comply with the mortgage and lease. ${ }^{128}$ Because the rent was paid directly to the noteholder, only a relatively insignificant amount of cash ever reached the nominal owner-lessor. ${ }^{129}$

The transactions in Bolger are remarkably similar to current synthetic lease transactions with three important exceptions. First, although the court did not treat the transactions separately, some of them involved sale-leasebacks. ${ }^{130}$ Second, the minimum rent and lease terms were sufficient to fully amortize the debt. ${ }^{131}$ Third, the financing corporation took one extra step-it subsequently conveyed the fee to an individual who reported the depreciation deductions. ${ }^{132}$ The subsequent conveyance was to Bolger or other shareholders, for a nominal consideration, subject to the lease and mortgage. ${ }^{133}$ The transferee executed an "assumption agreement" that was the antithesis of the normal assumption agreement because it stated that the transferee refused to assume personal liability on the mortgage. ${ }^{134}$ In short, the so-called assumption agreement provided that the transferee's liability was nonrecourse. One can only speculate that the agreement was

121. Id.

122. Id.

123. Bolger, 59 T.C. at 762 .

124. Id.

125. Id.

126. Id.

127. Id.

128. Bolger, 59 T.C. at 762.

129. Id. at 763 .

130. Id. at 765 (stating that neither party argued that variations among the fact pattems made a difference).

131. Id.

132. Id.

133. Bolger, 59 T.C. at 761 .

134. Id. at 762 . 
calculated, in an almost condescending way, to remind the Service of the lessons of Crane v. Commissioner. ${ }^{135}$

The Service argued that the financing corporation was an independent entity for federal income tax purposes and that it, rather than Bolger, had the depreciable interest. ${ }^{136}$ The Service failed to argue that the depreciable interest was in the lessees. ${ }^{137}$ Indeed, the Tax Court expressed frustration at the Service's failure to argue that the transactions were mortgages by the lessees and at its failure to separate the question of the existence of a depreciable interest from the question of the basis in that interest. ${ }^{138}$

The court agreed with the first two prongs of the Service's argument but rejected the Service's third prong. ${ }^{139}$ The court first concluded that the financing corporations were separate viable entities when the leases and financings were consummated. ${ }^{140}$ They were organized and used for business purposes, "namely, to enable the contemplated transactions to produce maximum financing by avoiding state law restrictions on loans to individuals rather than corporate borrowers, to provide a mechanism for limiting personal liability, and to facilitate multiple-lender financing." 141 The court stated, without further explanation, that the corporations were not mere agents or nominees of Bolger and the other transferees:

Indeed, the existence of an agency relationship would have been self-defeating in that it would have seriously endangered, if not prevented, the achievement of those objectives which, in large part, gave rise to the use of the corporations, namely, the avoidance of restrictions under state law. ${ }^{142}$

The court next concluded that the financing corporations remained "separate viable entities" after the transfers to Bolger and others, even though "they were stripped of their assets and, by virtue of their undertakings, could not engage in any other business activity." 143 The court noted:

[T] he corporations continued to be liable on their obligations to the lenders and were required under the terms of those obligations, to remain in existence, to abide by certain other undertakings, and to preserve their full powers under the applicable state laws to own property and transact business. Moreover, the transferees... agreed to cause the corporations to comply with their undertakings, albeit that any claim for breach of such agreement was limited to

135. 331 U.S. 1 (1947). See generally Donald J. Weidner, Realty Shelters: Nonrecourse Financing. Tax Reform, and Profit Purpose, 32 Sw. L.J. 711, 714-23 (1978).

136. Bolger, 59 T.C. at 769-70.

137. Id. at 767 n.5: "Respondent concedes that the leases involved should be recognized as such and makes no argument that the lessees are the ones to whom the benefit of a depreciation deduction should inure."

138. Id. at $769 \mathrm{n} .8$ :

[W]e note that the position of the lessor is sometimes also discussed in terms of his not having any basis. What is more, such discussion sometimes confuses the two questions, i.e., existence of a depreciable interest and the measure of basis, of which respondent's briefs herein furnished an excellent example.

139. Id. at 767.

140. Id. at 766 .

141. Bolger, 59 T.C. at 766.

142. Id.

143. Id. 
the property and could not constitute a basis for the assertion of personal liability. ${ }^{144}$

In short, the financing corporations remained separate entities after the transfers because they continued to serve a business purpose. "On the same basis," said the court, "we conclude that the corporations cannot be considered as agents of the transferees during the period following the transfers." 145 Because there was no direct attempt to recharacterize the leases as mortgages, the court was never presented with the question whether the financing corporations were agents of the tenants whose recourse rent obligations serviced the debt.

Having established that the financing corporations were separate taxable entities both before and after the transfers, the Service argued that Bolger and the other transferees acquired only a reversionary interest that did not rise to the level of a presently depreciable interest. ${ }^{146}$ The properties were encumbered by one hundred percent financing and the relationship between the debt service and the rent was such that the "owner" would have only a nominal cash flow for a very long time. ${ }^{147}$ Nevertheless, the Tax Court said that the nominal owner had sufficient equity to support a claim of a depreciable interest. ${ }^{148}$ The reversionary interest argument

ignores the fact ... that [Bolger's] equity in the property increases as the rents under the lease are paid in amortization of the mortgage. This increase in equity will benefit [Bolger] either by way of gain in the event of a sale or the creation of refinancing potential. Moreover, [Bolger] will seek to protect his interest in the property in order to retain the benefit of any appreciation in its fair market value. $^{149}$

In addition, the court stated that the Service stipulated away the reversionary interest argument by insisting that the financing corporations had a presently depreciable interest. ${ }^{150}$ The interest of the financing corporations passed to their transferees, said the court, and the only question that remained was the measure of their basis. ${ }^{151}$

144. Id. at 766-67.

145. Id. at 767 . The United States Supreme Court subsequently gave the real estate industry much more comfort concerning its ability to use corporate agents to acquire title to real property, even if "two different taxpayers can plausibly be regarded as the owner." Commissioner v. Bollinger, 485 U.S. 340, 345 (1988).

146. Bolger, 59 T.C. at 767.

147. Id.

148. Id.

149. Id. at 770 .

150. Id. at 767 :

Implicit in respondent's position is the concept that, by virtue of the leases and financing transactions, the corporations divested themselves of all but bare legal title to the properties. Following this concept to its logical conclusion would require a determination either that the corporations thereby deprived themselves of any presently depreciable interest or that their right to deduct the cost of the buildings should be by way of amortization over the lease terms. But both possibilities are belied by respondent's basic argument that the corporations retained such an interest in the properties as against their transferees that they, and not the latter, should be held accountable for the income from the properties and be entitled to the depreciation deduction.

151. Bolger, 59 T.C. at $760,767$. 
The Tax Court's analysis of Bolger's basis was simple. Had the purchase money mortgages, which did not exceed the value of the properties, been recourse, they would have been included in Bolger's depreciable basis. Crane v. Commissioner ${ }^{152}$ and its progeny ${ }^{153}$ give the taxpayer an advance credit for the amount of the mortgage on the premise that an investment in the amount of the mortgage will eventually occur despite the absence of personal liability. ${ }^{154}$ Bolger should not be penalized simply because he achieved one hundred percent nonrecourse financing of a property that threw off just enough cash to service the debt. ${ }^{155}$ The court found no way of sugarcoating Crane's "bitter pill."156

The transactions in Bolger were mortgages by the lessees. Nevertheless, the Service failed to note that the emperor wore no clothes. It never argued that the lessees were the owner-mortgagors and hence the proper parties to report depreciation deductions. The result was that depreciation deductions were stripped from the true owner-borrowers and assigned first to the SPEs, which in turn assigned them to their shareholders, apparently as compensation for orchestrating the mortgages. ${ }^{157}$ What was missing in Bolger was present in each of the next three cases discussed in this section: a direct assault on the classification of the leases. The Service attempted to call a lease a mortgage and was successful in two out of three cases.

\section{Sun Oil: A Lease Is Deemed a Mortgage}

Sun Oil Co. v. Commissioner 158 involved a corporation that wanted to raise working capital without incurring debt on its books. ${ }^{159}$ Sunray "sold" 320 unimproved gasoline service station sites ${ }^{160}$ at $\operatorname{cost}^{161}$ to the General Electric Pension Trust (Trust), and

152. 331 U.S. 1 (1947).

153. See especially Mayerson v. Commissioner, 47 T.C. 340 (1966).

154. Crane, 331 U.S. at 14; Mayerson, 47 T.C. at 351-52.

155. Bolger, 59 T.C. at 771 :

Every owner of rental property hopes to recoup his investment plus a profit, from the receipt of rental income. In the normal case, he applies part of this income to the amortization of any mortgage encumbering the leased property, retaining any excess over the mortgage payments as his cash flow. [Bolger's] case should not be treated differently merely because his acquisition of the property is completely financed and because his cash flow is minimal.

Judges Goffe, Quealy, and Scott filed separate dissents to Judge Tannenwald's opinion.

156. Id. at 771 .

157. For an article by an extremely thoughtful real estate practitioner indicating amazement at the enormity of the taxpayer's victory, see Alvin D. Lurie, Bolger's Building: The Tax Shelter that Wore No Clothes, 28 TAX L. REV. 355 (1973).

158. 562 F.2d 258 (3d Cir. 1977).

159. Id.

160. Id. The case actually dealt with two different letter agreements, one for 120 sites and one for 200 sites. Id. at 260 . The two agreements were structured the same, but at slightly different interest rates. Id. For the sake of simplicity, only the rates in the first agreement are specified in this article.

161. Sun Oil, 562 F.2d, at 260 n.3:

Sunray agreed to convey the properties at cost because it believed there would be no substantial difference between the appraised value and Sunray's cost of acquisition, most acquisitions having been made during the preceding 18 months. This also relieved Sunray of the necessity for expensive and time consuming appraisals. 
simultaneously "leased" them back for a primary term of 25 years. ${ }^{162}$ Rent was not computed on the basis of appraising the property by capitalizing earnings. Rather, quarterly rent was sufficient to enable the Trust to amortize its investment in full over the initial term at an interest return of $45 / 8 \%$ on investment. ${ }^{163}$ The lease also gave Sunray options to renew the lease for two five-year terms at annual rent equal to $21 / 2 \%$ of the purchase price and for an additional eleven five-year terms at annual rental equal to 1 $1 / 2 \%$ of the purchase price. ${ }^{164}$ In short, the leases gave Sunray control of the property for 90 years at declining rents. ${ }^{165}$ Sunray reported the transactions in a footnote on its balance sheet rather than as a liability, minimizing any impact on its credit rating. ${ }^{166}$

Sunray had several ways to cancel the leases. First, the leases gave Sunray options to repurchase the properties on specified dates in the event it decided to discontinue using the property. ${ }^{167}$ The option price was equal to the property's "fair appraised value ... to Lessor," 168 which meant as encumbered by the leases. 169 Second, Sunray could terminate its obligation to lease any property that proved uneconomical as a service station site. ${ }^{170}$ Each lease gave Sunray the right to make "a rejectable offer to purchase" the property, as of any rent payment date, at a price "equal to the sum of the present values ... of all quarterly Basic Rent payments to become due" plus an amount sufficient to insure the Trust of a return of five percent per annum over the term of the investment. ${ }^{171}$ The Trust was given thirty days to consider a rejectable offer. ${ }^{172}$ If the Trust were to reject an offer, Sunray would be released from its obligations under the lease. ${ }^{173}$ Third, in lieu of making a rejectable offer to purchase, Sunray could substitute for the Leased Premises other property (to consist of land only) having a then value at least equal to the rejectable offer to purchase consideration which otherwise would have been applicable. ${ }^{174}$ Within ten years of the agreement, Sunray made over 130 rejectable offers to repurchase, which were all accepted by the Trust. ${ }^{175}$

Because no depreciable asset was involved, the question was simply whether Sunray was permitted to deduct all the "rent" it paid. The Service was concerned that the form of

162. Id
163. Id
164. Id
165. Id.

It is hardly conceivable that an owner of real estate-especially a large sophisticated trustconcerned with a fair rental on its land rather than a retum of its loan and interest, would enter into a lease with sharply declining rentals for sixty-five years following the conclusion of the primary term....

166. Sun Oil, 562 F.2d at 260.

167. Id. at $260-61$.

168. Id. at 267 (internal quotations omitted).

169. The court pointed out that, in the absence of a provision to the contrary, appraisers must consider leases as encumbrances. Id. at 268 . Here, the "fair appraised value to Lessor" was hardly a provision to the contrary: "Thus, ... the appraisers would have to consider the encumbrances of the properties with leases of very low rentals, thereby seriously reducing the present value of future rentals." Id.

170. Sun Oil, 562 F.2d at 269.

171. Id.

172. Id at 261 .

173. Id. at 263.

174. Id. at 264.

175. Sun Oil, 562 F.2d at 265. 
a lease was being used to create a deduction when the tax-exempt status of the lessor precluded an offsetting inclusion in income. ${ }^{176}$ The Service relied on Section 162(a), which authorizes a deduction for the rental "of property to which the taxpayer has not taken or is not taking title or in which he has no equity."177 The Service argued that Sunray retained an equity. ${ }^{178}$ More broadly, the Service argued that Sunray retained all the benefits and burdens of ownership, and that the transaction was nothing more than an elaborate financing device in which the Trust made a secured loan to Sunray. ${ }^{179}$ Under this analysis, Sunray could deduct only the portion of the "rent" that was traceable to a payment of interest and not the portion attributable to the repayment of principal. ${ }^{180}$

The Third Circuit, after a bad false start, ${ }^{181}$ recognized that the benefits and burdens of ownership can be allocated any number of ways between a landlord and a tenant of commercial real estate. ${ }^{182}$ No single conception of ownership drives all transactions: "The usual business bargain between a commercial lessor and lessee is far more complex. Real estate interests between a lessor and lessee normally are divided into a number of parts, each of which represents an ownership interest in property."183

The Third Circuit quoted, with approval, the following "pragmatic" approach to deciding substance-over-form arguments in real estate leasing transactions: "[T]he inquiry must change from 'Who is the owner of the property for tax purposes?' to 'Are the ownership interests of lessor and lessee as characterized by the parties consistent with traditional substantive business bargains between lessors and lessees?"'184 The court concluded that neither the burdens nor the benefits were allocated consistent with traditional substantive business bargains between lessors and lessees. ${ }^{185}$ The case is instructive for current synthetic leases with similar allocations of benefits and burdens. Indeed, Sun Oil has been used as a model in planning synthetic lease transactions.

The lease went beyond a typical triple-net lease that puts the burden of all maintenance, repairs, and taxes on the tenant. It also relieved the landlord of all obligation to rebuild or to make any other expense in connection with the lease. Sunray agreed to an absolute and unconditional obligation to pay rent, without deduction or setoff, even in the event of casualty or condemnation of the property. ${ }^{186}$ It also agreed to indemnify the Trust and to hold it harmless from any liabilities arising from the use of the property. ${ }^{187}$

\footnotetext{
176. Id.

177. I.R.C. § 162(a)(3) (1986).

178. Sun Oil, 562 F.2d at 265.

179. Id. at 267.

180. Id.
}

181. The Third Circuit began its opinion by stating that "[a] recurring question in transactions of this sort is whether after the transfer of title to the property some or all of the critical incidents of ownership still remain with the grantor despite his newly designated status as lessee." Id. at 259.

182. Id.

183. Sun Oil, 562 F.2d at 262.

184. Id. at 262 (citing Alan S. Rosenberg \& Herbert T. Weinstein, Sale-Leasebacks: An Analysis of These Transactions After the Lyon Decision, 45 J. TAX'N 146, 148 (1976)).

185. Sun Oil, 562 F.2d at 262.

186. Id. at 263.

187. Id. 
Sunray also controlled important benefits of ownership traditionally reserved to the owner. For example, Sunray was empowered to negotiate the terms of any taking of the property and to transfer the property without prior approval or joinder of the Trust. ${ }^{188}$ The court sifted through every aspect of the transaction to determine, for example, who had the benefit of cash from current operations, who received cash from refinancing, who received cash from condemnation or casualty, and who received cash from the sale of the property. ${ }^{189}$ The court found that the tenant had virtually all these beneficial aspects of ownership. ${ }^{190}$ Sunray held the benefits of the property's appreciation in value by virtue of its right to make rejectable offers to purchase, which the Court found to be, in substance, not rejectable. ${ }^{191}$

What is particularly instructive for synthetic lease transactions is the court's refusal to accept the formal allocation of benefits and burdens. It summarily dismissed the fact that the properties were transferred at fair market value, which could be explained either by a sale or by one hundred percent financing. ${ }^{192}$ Influenced in part by Sunray's right to substitute other properties, the court refused to be swayed by the Trust's formal right to reject an offer to purchase:

The limitations of time, distance, and subject matter also erode whatever substance may have existed in the lessor's rights to reject an offer. The Trust had only thirty days after the receipt of rejectable offers to reject them and the failure to act was deemed to be an acceptance. The offers left the Trust with virtually an impossible task of securing independent appraisals on comparative low unit value properties, securing competent advice, and reaching an intelligent, considered decision within a short time on multiple pieces of diverse properties geographically dispersed over many states. Rejecting the offer would have required the Trust, having no employees with background or experience in real estate management, to undertake the heavy burden of managing small real estate parcels and properties scattered over 17 states. The acceptance of such a burden was viewed ... a being inconsistent with the investment goals of this $21 / 2$ billion dollar trust. ${ }^{193}$

If it was not practical for a $\$ 2.5$ billion trust to weigh rejectable offers to purchase, in part because it lacked the requisite staff of real estate professionals, a fortiorari it would not be practical for typical SPEs in synthetic lease transactions to exercise such rights. Unlike the pension trust involved in Sun Oil, the typical SPE in a synthetic lease transaction is nothing more than a series of bookkeeping entries. The SPE typically guarantees it will have no business at all other than entering into designated synthetic

188. Id. at 264 :

We view the retention of such broad powers by the lessee in the event of condemnation or government seizure of the land, especially the power to negotiate the price for the land, and the absence of rent abatement in the event of a partial taking and continued occupancy of the balance as inconsistent with the traditional role of a lessee.

189. Id.

190. Sun Oil, 562 F.2d at 264.

191. Id.

192. Id.

193. Id. at 265 . 
lease transactions; i.e., it promises that it will buy no assets, incur no obligations and hire no employees.

Stated somewhat differently, the very purpose of the SPE is to obtain off-balance sheet financing for the nominal tenant by segregating choice assets and keeping them from the hands of other creditors. Like the college involved in the landmark Century Electric case of decades past, today's SPE agrees to be a "friendly landlord."194 Friendly lessors do not reject their lessees' offers. In many cases, it is clear that an SPE is an agent of a corporate tenant under a fiduciary obligation to refrain from declining offers that are, on their face, "rejectable." This will generally not be explicit, for fear of nunning afoul of financial accounting standards. In other words, the SPE is actually created and paid to receive a small piece of the transaction-enough of a piece so that the lease qualifies as an operating lease for financial accounting purposes. Otherwise, the SPE is expected to help achieve the lessee's goals. ${ }^{195}$

Throughout the Sun Oil opinion, the Third Circuit cited the Eighth Circuit's opinion in Frank Lyon Co. v. United States. ${ }^{196}$ Although the vitality of Sun Oil might be cast into doubt by the Supreme Court's reversal of the Eighth Circuit's decision in Frank Lyon Co., the Supreme Court's opinion suggests that taxpayers may indeed continue to rely on a benefits and burdens analysis of the sort detailed in Sun Oil, provided they are not trying to take inconsistent reporting postures or otherwise take advantage of a divergence in tax status between lessor and lessee. ${ }^{197}$

\section{Frank Lyon Co.: The Supreme Court Fails to Recognize That a Lease Is a Mortgage}

In Frank Lyon Co., ${ }^{198}$ Worthen Bank (Bank) owned a parcel of land and wanted to finance and construct a new building on it. ${ }^{199}$ The Bank entered into a sale-leaseback of the building at the insistence of regulatory authorities who would not permit such an expensive asset on the Bank's books. ${ }^{200}$ The Bank entered into a transaction with taxpayer Frank Lyon Company (Lyon Company), a closely held corporation engaged in the distribution of electrical appliances and other home furnishings. ${ }^{201}$ Frank Lyon was Lyon Company's majority shareholder and board chair and was also a member of the Bank's board. ${ }^{202}$ In short, the Bank: (1) retained title to the land; (2) leased the land to Lyon Company; (3) "sold" the building, as it was constructed, to Lyon Company; (4) "leased" the building back; and (5) received a number of options to repurchase the

194. Century Elec. Co. v. Commissioner, 192 F.2d 155, 157 (8th Cir. 1951) (referring to a "friendly landlord" transaction, said that not enough changed to allow the grantor-lessee to recognize a loss on a purported sale-leaseback).

195. See the description of the "synthetic leasing" arrangement in Unocal Corp. v. Kaabipour, 177 F.3d 755 (9th Cir. 1999), especially the relationship between the SPE and the tenant.

196. Frank Lyon Co. v. United States, 536 F.2d 746 (8th Cir. 1976), judgment rev'd, 435 U.S. 561 (1978).

197. See Frank Lyon Co. v. United States, 435 U.S. 561,583 (1978).

198. 435 U.S. 561 (1978).

199. Id.

200. Id. at 564 .

201. Id. at 563 .

202. Id. 
building. ${ }^{203}$ Consistent with its formal ownership of the building, Lyon Company reported depreciation deductions on its cost. 204

The financing of the building began in earnest when the Bank obtained a commitment from New York Life Insurance Company (New York Life) to provide $\$ 7.14$ million in permanent mortgage financing, conditioned upon New York Life's approval of the titleholder. Lyon Company, after approval by New York Life, agreed to buy the building from the Bank for a total price not to exceed $\$ 7.64$ million in reimbursements to the Bank for its construction expenditures. ${ }^{205}$ The Bank executed a deed of trust to the land and to an adjoining parking complex to secure the New York Life loan. ${ }^{206}$ The actual cost of the office building and parking complex exceeded $\$ 10$ million. ${ }^{207}$ Lyon Company agreed to pay the $\$ 7.64$ million by making a $\$ 500,000$ cash down payment and by executing a $\$ 7.14$ million mortgage. ${ }^{208}$ The Service took the position that the leases and options made the Bank the substantive owner such that the Bank, rather than Lyon Company, was the party entitled to depreciation deductions. ${ }^{209}$ Under this analysis, Lyon Company was merely a second mortgagee that served as a conduit for the debt service on the New York Life first mortgage.

The financing was consummated when the Bank executed a seventy-six-year ground lease to Lyon Company and contemporaneously received a building lease that, with renewal options, was for sixty-six years. ${ }^{210}$ For the first twenty-six years, Lyon Company had a negative cash flow of fifty dollars per year as a result of the transactions with the Bank. ${ }^{211}$ The annual ground rent to the Bank was fifty dollars a year and the annual $\$ 600,000$ rent due from the Bank on its lease of the building exactly equaled the annual debt service on the New York Life mortgage. ${ }^{212}$ The Bank's obligation to pay rent on the building was typical of a triple-net tenant, obligating it to pay all maintenance, repairs, taxes, and insurance. ${ }^{213}$ In addition, the Bank's obligation to pay net rent was absolute and unconditional, even in the event of destruction of the building. ${ }^{214}$ After the initial twenty-six-year term, the Bank had eight additional five-year renewal terms at rent that was cut in half: to $\$ 300,000$ per year. ${ }^{215}$ During this same period, the ground rent was increasing. ${ }^{216}$ For the ten years by which the ground lease exceeded the building lease renewal options, the ground rent was slashed to $\$ 10,000$ per year. ${ }^{217}$

Contemporaneous with the ground and building leases, the Bank was also given options to "repurchase" the building at the end of years eleven, fifteen, twenty, and

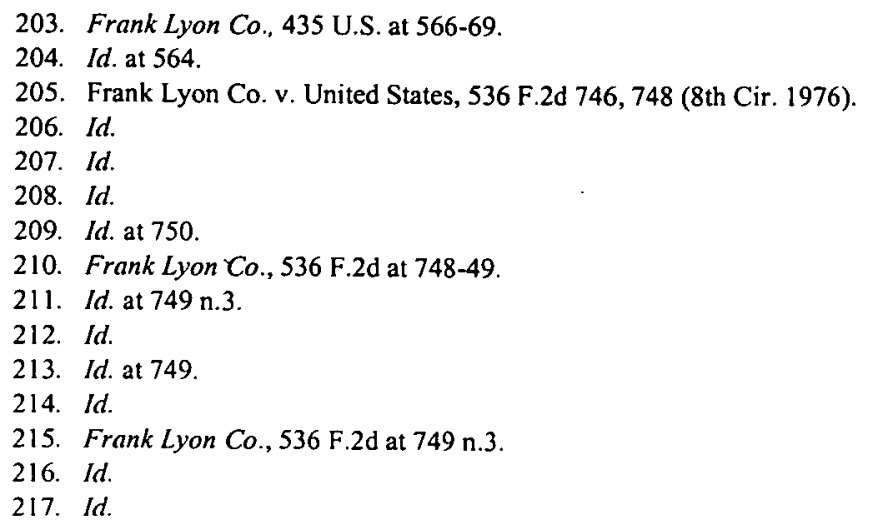


twenty-five. ${ }^{218}$ In each case, the option price was an amount equal to the sum of the following: (1) the unpaid balance of the New York Life mortgage; (2) the $\$ 500,000$ advanced by Lyon Company; and (3) $6 \%$ compound interest on $\$ 500,000.219$ In substance, the Bank could repurchase at any time by prepaying the New York Life first mortgage and by repaying Lyon Company's second mortgage with accrued interest.

The Eighth Circuit had accepted the Service's argument that, despite the form of the transaction, the Bank, not Lyon Company, owned the building. ${ }^{220}$ It analogized ownership to a "bundle of sticks" and concluded that Lyon Company "totes an empty bundle." 221 It applied a "benefits and burdens" analysis and emphasized that all the benefits of ownership were in the Bank. ${ }^{222}$ The leases and options left all control in the Bank. ${ }^{223}$ The option prices left a right in the Bank to capture all appreciation in the value of the building simply by repaying monies advanced plus interest. ${ }^{224}$ Judge Bright stated that any condemnation awards in excess of the monies advanced were to be paid to the Bank. ${ }^{225}$ In short, the only economic advantages to Lyon Company's "ownership" were the income tax advantages from the depreciation deductions in the first eleven years of the property's useful life. ${ }^{226}$

The Supreme Court's opinion reversing the Eighth Circuit made several basic points. ${ }^{227}$ First, it distinguished Lazarus and Sun Oil on the ground that they were twoparty cases, noting that Sun Oil had "the added feature that the second party was a taxexempt pension trust."228 Frank Lyon Co., the Court said, involved three parties, Lyon Company, the Bank, and New York Life. ${ }^{229}$ Second, the Court noted that the transaction in Frank Lyon Co. was "compelled by the realities of the restrictions imposed upon the bank" 230 by government. Third, the Court said that none of the parties owned the building in any simple sense. ${ }^{231}$ Fourth, the Court said that, within reasonable limits, the taxpayers in a leasing transaction may allocate depreciation deductions to a lessor who retains significant attributes of traditional lessor status. ${ }^{232}$ Stated differently, the Court declared that, within reason, taxpayers may control substance with form:

In short, we hold that, where, as here, there is a genuine multiple-party transaction with economic substance which is compelled or encouraged by business or regulatory realities, is imbued with tax-independent considerations,

\footnotetext{
218. Id. at 752 .

219. Id.

220. Frank Lyon Co., 536 F.2d at 754.

221. Id. at 751 .

222. Id. at 754 .

223. Id. at 752 .

224. Id.

225. Frank Lyon Co., 536 F.2d at 749. Lyon Company took the position that it was entitled to any net condemnation awards prior to the time of the Bank's first repurchase option. Frank Lyon Co. v. United States, 435 U.S. 561,571 n.7 (1978).

226. Frank Lyon Co., 536 F.2d at 749.

227. Frank Lyon Co., 435 U.S. at 575.

228. Id.

229. Id.

230. Id.

231. Id.

232. Frank Lyon Co., 435 U.S. at 581.
} 
and is not shaped solely by tax-avoidance features that have meaningless labels attached, the Government should honor the allocation of rights and duties effectuated by the parties. Expressed another way, so long as the lessor retains significant and genuine attributes of the traditional lessor status, the form of the transaction adopted by the parties governs for tax purposes. ${ }^{233}$

The Court emphasized that considerable risk fell on Lyon Company, which was not an SPE, but a substantial, ongoing business. ${ }^{234}$ The Court said that Lyon Company, not the Bank, was liable on the note. ${ }^{235}$ Lyon Company disclosed the liability on its financial statements and incurred the opportunity cost of foregone financing. ${ }^{236}$ The Court also said that Lyon Company was not even assured of a return of its money plus six percent. ${ }^{237}$ If the Bank exercised all its lease renewal options, Lyon Company would be left to the last ten years of its ground lease to make a six percent profit. Even if the Bank declined to exercise its lease renewal options, Lyon Company nevertheless remained liable on the ground lease. 238 "This possibility brings into sharp focus the fact that Lyon [Company], in a very practical sense, is at least the ultimate owner of the building."239 Unless the Bank were to exercise one of its purchase options, said the Court, there was no promise to repay Lyon Company its $\$ 500,000$ plus six percent interest. ${ }^{240}$ In light of the district court finding that the purchase options were not likely to be exercised, the Supreme Court refused to "speculate" that the options would be exercised. ${ }^{241}$ No promise to repay meant no second mortgage.

The lessons of Frank Lyon Co. must be teased out of a Supreme Court statement of rationale that is one of the longest run-on sentences in Anglo-American law. ${ }^{242}$ The

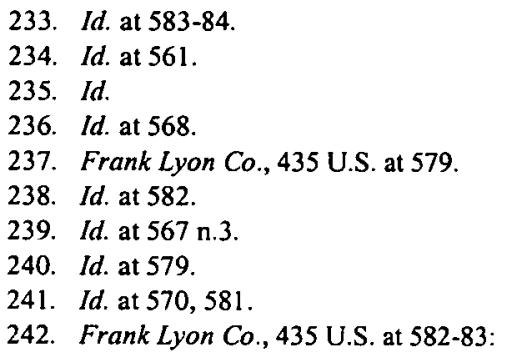

We however, as did the District Court, find this theorizing incompatible with the substance and economic realities of the transaction: the competitive situation as it existed between Worthen and Union National Bank in 1965 and the years immediately following; Worthen's undercapitalization; Worthen's consequent inability, as a matter of legal restraint, to carry its building plans into effect by a conventional mortgage and other borrowing; the additional barriers imposed by the state and federal regulators; the suggestion, forthcoming from the state regulator, that Worthen possess an option to purchase; the requirement, from the federal regulator, that the building be owned by an independent third party; the presence of several finance organizations seriously interested in participating in the transaction and in the resolution of Worthen's problem; the submission of formal proposals by several of those organizations; the bargaining process and period that ensued; the competitiveness of the bidding; the bona fide character of the negotiations; the three-party aspect of the transaction; Lyon's substantiality and its independence from Worthen; the fact that diversification was Lyon's principal motivation; Lyon's being liable alone on the successive notes to City Bank and New York Life; the reasonableness, as the District Court found, of the rentals and of the option prices; the substantiality of the purchase prices; Lyon's not being engaged generally in the business of financing; the presence of all building depreciation risks on Lyon; the risk borne by Lyon, that 
philosophy seems to be as follows. First, the allocation of benefits and burdens in commercial real estate transactions follows no single simple pattern. Depreciation deductions will frequently be allocated to a taxpayer who is not the "owner" in a pure sense. Second, there is more sympathy for a taxpayer's claim to ownership for federal income tax purposes if there is no whipsaw of the Government. In Frank Lyon Co., the lessor and lessee were consistent in their reporting postures and each was consistent from year-to-year. ${ }^{243}$ Both were ongoing businesses. Unlike Sun Oil, the Court did not perceive that there was any special advantage being taken of a divergence in accounting method or federal income tax status: 244

[T]he Government is likely to lose little revenue, if any, as a result of the shape given the transaction by the parties. No deduction was created that is not either matched by an item of income or that would not have been available to one of the parties if the transaction had been arranged differently. ${ }^{245}$

The Court's analysis is disappointing. It should not have considered Lyon Company a traditional owner-lessor. There was no way to claim that Lyon Company had any significant benefits of ownership. It was clear that the Bank controlled the use of the building for its entire useful life and that its options to purchase the building captured all potential appreciation in value. The only possible exception is based on Lyon Company's assertion that it was entitled to condemnation proceeds in excess of the mortgage if the property were condemned prior to the date of the Bank's first repurchase option in year eleven. ${ }^{246}$ However, even if the assertion were correct, it was extremely unlikely that one of Arkansas' newest and largest skyscrapers would be condemned. ${ }^{247}$ In addition to having all the benefits of ownership, the Bank also bore virtually all the burdens of ownership. The lease placed all costs of operating the property on the Bank. ${ }^{248}$ In addition, the Bank unconditionally promised to pay net rent in the full amount of the New York Life loan and further secured that loan by a deed of trust on the land under the

Worthen might default or fail, as other banks have failed; the facts that Worthen could "walk away" from the relationship at the end of the 25-year primary term, and probably would do so if the option price were more than the then-current worth of the building to Worthen; the inescapable fact that if the building lease were not extended, Lyon would be the full owner of the building, free to do with it as it chose; Lyon's liability for the substantial ground rent if Worthen decides not to exercise any of its options to extend; the absence of any understanding between Lyon and Worthen that Worthen would exercise any of the purchase options; the nonfamily and nonprivate nature of the entire transaction; and the absence of any differential in tax rates and of special tax circumstances for one of the parties-all convince us that Lyon has far the better of the case. (footnotes omitted).

243. Id.

244. Id. at 583 .

245. Id. at 580. But see Bemard Wolfman, The Supreme Court in the Lyon's Den: A Failure of Judicial Process, 66 CORNELL. L. REV. 1075 (1981). Professor Wolfman points out that the opportunity for mischief was far greater than the Court appreciated. Frank Lyon Company had accumulated earnings to the extent that it needed to diversify to avoid a penalty and Worthen Bank, as a commercial bank, had flexibility that was not available to other corporations. See id. at 1094-1101.

246. Frank Lyon Co., 435 U.S. at 571.

247. Compare to the Hilton court's refusal to consider as significant the allocation of proceeds in a highly unlikely condemnation. See infra note 297.

248. Frank Lyon Co., 435 U.S. at 571. 
building and on the Bank's adjoining parking garage. ${ }^{249}$ It is true that there was, on paper, the possibility that the Bank might never exercise any of its options to repurchase the building from Lyon Company. ${ }^{250}$ As a result, there was no explicit promise to pay Lyon Company its $\$ 500,000$ plus interest. However, this fact is also consistent with a nonrecourse loan from Lyon Company, and the building would have had to dramatically decrease in value for Lyon Company to go unpaid. In addition, it also seemed unlikely that Lyon Company would leave Worthen Bank with a collapsed tax shelter or otherwise unsatisfied. Frank Lyon Company was a friendly lessor with common board members and common counsel. ${ }^{251}$ If the General Electric Pension Trust in Sun Oil was not about to begin operating service station sites, a fortiorari the appliance dealership in Frank Lyon Co. was not about to begin operating a skyscraper. The Service's basic analysis was correct: the transaction was a mortgage by the tenant with a second mortgage from a friendly title holder.

It was unclear to what extent Frank Lyon Co. would be followed, confined to its facts, or distinguished as a case involving a government-compelled transaction. ${ }^{252}$ It was not until Hilton that the Tax Court applied Frank Lyon Co. to a garden-variety real estate leasing transaction involving an SPE. Although the Hilton court purported to follow the letter of Frank Lyon Co., it very clearly put the brakes on taxpayer attempts to allocate depreciation deductions by elevating form over substance.

\section{Hilton Reverses Bolger And Narrowly Applies Frank Lyon to Recharacterize a Lease as a Mortgage}

In Hilton v. Commissioner, 253 the Tax Court dealt with facts that "closely parallel the rather paradigmatic facts (particularly where State law usury problems are encountered) of Bolger v. Commissioner." 254 Although in Bolger the Service made "no argument that the lessees are the ones to whom the benefit of a depreciation deduction should inure," in Hilton, the Service "does not so blithely abandon ship and it is the efficaciousness of the lease, itself, which he now frontally attacks." 255

In 1964, Broadway, a large department store chain, decided to build a retail outlet in a proposed shopping mall in Bakersfield, California. ${ }^{256}$ Although Broadway was going to

\footnotetext{
249. Id. at $570-71$.

250. Id.

251. See Wolfman, supra note 245 , at 1098 :
}

It is not credible that Worthen and Lyon, while sharing the same tax lawyer, with both Mr. Lyon and the lawyer sitting on the Worthen board, were unaware of their differing tax needs and the way each might be helpful to the other at the expense of only the United States Treasury.

252. See Stanton H. Zarrow \& David E. Gordon, Supreme Court's Sale-Leaseback Decision in Lyon Lists Multiple Criteria, $49 \mathrm{~J}$. TAX'N 42, 47 (1978), in which the authors state that Frank Lyon Company "may actually only benefit the Commissioner, who will be able to show that few, if any, future cases are ones where all the Lyon factors are present." See also Wolfman, supra note 245, at 1100: "Until the time comes when the Court can undo the mischief of Frank Lyon, one hopes that the Service and lower courts will see it as a case whose precedential significance is impaired substantially by the flawed process from which it emerged."

253. 74 T.C. 305 (1980), aff'd per curiam 671 F.2d 316 (9th Cir. 1982).

254. Hilton, 74 T.C. at $348-49$.

255. Id. at 349.

256. Id. at 308 . 
finance construction internally, it intended to obtain long-term financing on completion of construction. ${ }^{257} \mathrm{~A}$ single-purpose financing corporation, Fourth Cavendish, was created for the sole purpose of facilitating this one transaction. ${ }^{258}$ The stock of Fourth Cavendish was held in the name of a New York investment firm that served as the intermediary in negotiating the transaction between Broadway and the insurance companies. ${ }^{259}$ Fourth Cavendish was to sell its corporate notes to insurance company lenders. ${ }^{260}$ The insurance companies committed to provide the financing by buying the notes once the building was completed. ${ }^{261}$ Funds derived from the sale of the notes would be used to pay the purchase price to Broadway. ${ }^{262}$ Simultaneous with the sale, Fourth Cavendish would lease the property back to Broadway. ${ }^{263}$

The sale of the notes funded the entire cost of the purchase ${ }^{264}$ Broadway even paid the commitment fees and commissions for arranging the sale of the notes. ${ }^{265}$ The lease back to Broadway was a triple-net lease for a thirty-year term, with options for Broadway to extend for another sixty-eight years. ${ }^{266}$ The notes were secured by a deed of trust conveying Fourth Cavendish's interest in the properties to the trustee for the insurance companies and by an assignment of the lease and the rentals to the trustee. ${ }^{267}$ Contemporaneous with the above, Fourth Cavendish transferred its interest to a general partnership that was formed to receive it. ${ }^{268}$ The taxpayers were the partners who were assigned the interest of Fourth Cavendish.

The financing and lease were structured "so that Broadway's relationship with the property remained virtually unchanged." 269 The triple-net lease absolved Fourth Cavendish of any financial obligation relating to the property except the obligation to pay monthly debt service, and "[e]ven this obligation was structured so that it would place no burden on Fourth Cavendish." 270 Rent payments were calculated to provide the lessor with just enough money to pay the debt service for the thirty-year term of the insurance company financing. ${ }^{271}$ Indeed, Broadway paid the rent directly to the insurance companies:

The transaction was further structured so that when Fourth Cavendish or its assignee completes paying off the financing [due over the thirty-year term], rental payments (assuming renewal options are exercised by Broadway) will be

257. Id. at 343-44.

258. The Tax Court noted, but did not treat as significant, that Fourth Cavendish was also used to finance two additional stores. $I d$. at 343 .

259. Hilton, 74 T.C. at 344.

260. Id.

261. Id.

262. Id.

263. Id.

264. Hilton, 74 T.C. at 344.

265. Id.

266. Id.

267. Id.

268. One of the partners was a limited partnership. The tax court referred to the "tier partnership labyrinth." Id. at 346.

269. Hilton, 74 T.C. at 344

270. Id.

271. Id. 
reduced to $11 / 2$ percent of the purchase price for the first renewal term of 23 years and to 1 percent of the purchase price for the second and third renewal terms. $^{272}$

According to Judge Nims, "the central issue in this case is the bona fides of the saleleaseback. This is essentially an exercise in substance versus form. . ."273 Judge Nims concluded that Hilton did not fall within the Frank Lyon Co. rule that taxpayers may select substance with their form. ${ }^{274}$ "[W]e do not understand the teaching of the Supreme Court's decision in that case to be that we are to accept every putative sale-leaseback transaction at face value." 275 The transaction must be tested to determine whether it "(1) is genuinely multiple-party, (2) with economic substance, (3) compelled or encouraged by business realities, ... and (4) is imbued with tax-independent considerations which are not shaped solely by tax-avoidance features."276 The Tax Court concluded that the transaction was not genuinely multiple-party within the meaning of Frank Lyon Company. ${ }^{277}$

It was not sufficient that, when looked at from the point of view of Broadway, as seller-lessee, the transaction had economic substance and was encouraged by business realities. The court accepted as a given that the sale-leaseback form enabled Broadway to obtain more financing and at lower cost than otherwise would have been available and also enabled Broadway to avoid earlier credit agreements limiting the debt it could incur. ${ }^{278}$ The transaction also must be "economically meaningful" from the point of view of the buyer-lessor. ${ }^{279}$ The court did "not deem the existence of a net lease, a nonrecourse mortgage, or rent during the initial lease term geared to the cost of interest and mortgage amortization to be, in and of themselves, much more than neutral commercial realities." 280 Indeed, even the fact that the transaction was put together by an "orchestrator" would "not alone prove fatal to the buyer-lessor's cause, provided the result is economically meaningful on both sides of the equation."281

Judge Nims first phrased the question as follows: "[D]oes the buyer-lessor's interest have substantial legal and economic significance aside from tax considerations, or is that interest simply the purchased tax byproduct of [the tenant's] economically impelled arrangement with the insurance companies?"282 Citing Estate of Franklin $v$. Commissioner, ${ }^{283}$ the court also offered an alternative statement of the question: "Could the buyer-lessor's method of payment for the property be expected at the outset to rather

272. Id. at $344-45$.

273. Id. at 346 .

274. Hilton, 74 T.C. at 364.

275. Id. at 346.

276. Id . at 347.

277. Id at $347-48$.

278. Id. at 347.

279. Hilton, 74 T.C. at 348.

280. Id.

281. Id.

282. Id.

283. Franklin's Estate v. Commissioner, 544 F.2d 1045 (9th Cir. 1976), aff'g Estate of Franklin v. Commissioner, 64 T.C. 752 (1975). Estate of Franklin is famous for announcing the "imprudent abandonment" test to determine whether depreciation and interest deductions may be taken by a purported purchaser when the seller provides nonrecourse purchase money financing. See also I.R.C. $\S 465(b)(6)$ (1986). 
quickly yield an equity which buyer-lessor could not prudently abandon?"284 Under this approach, the court considers "whether the foreseeable value of the property to the buyerlessor would ever make abandonment imprudent." 285 If not, there is no "investment" to depreciate.

Even based on the taxpayer's assumption that the property could always be sold for its original cost, said the court, "the present value of the property determined on a conservative actuarial basis would not be indicative of economic substance." 286 First, there was no cash flow to value for the first thirty years, when the rent was fully committed to service the debt. ${ }^{287}$ Second, cash flow for the next twenty-three years was reduced by the estimated cost of refinancing the ten percent balloon that was due at the end of the initial thirty-year term. ${ }^{288}$ The Government's expert testified that, in light of the life span of the residential properties the store was likely to serve, it was extremely likely that Broadway would exercise its option to renew for a twenty-three-year term. ${ }^{289}$ This expert also concluded that it was too speculative to project that Broadway would opt to exercise any renewals past fifty-three years. ${ }^{290}$ Therefore, he added the present value of the right to receive the property at the end of fifty-three years to the present value of the cash flow over years thirty-one through fifty-three. ${ }^{291}$ The total fell significantly short of the amount the financing corporation's assignees paid for their interest. ${ }^{292}$

In the end, the Tax Court refused to permit the financing corporation's assignees to claim ownership of the depreciable interest. ${ }^{293}$ After reviewing a present value analysis of the cash flows, the Tax Court was persuaded

that an objective economic analysis of this transaction from the point of view of the buyer-lessor, and therefore the [assignees of the SPE], should focus on the value of the cash flow derived from the rental payments and that little or no weight should be placed on the speculative possibility that the property will have a substantial residual value at such time, if ever, that Broadway abandons the lease. The low rents and almost nominal cash flow leave little room for doubt that, apart from the tax benefits, the value of the interest acquired by the petitioners is substantially less than the amount they paid for it. ${ }^{294}$

What is striking is the Tax Court's refusal to make assumptions that would benefit the lessor's claim to a depreciable interest. The court assumed that the tenant would exercise its favorable option to renew for years thirty-one through fifty-three and considered the net cash flow that would be generated during that renewal period after debt service to

284. Hilton, 74 T.C. at 350.

285. Id.

286. Id. at $\mathrm{n} .23$.

287. Id. at 354 .

288. Id. at 355 .

289. Hilton, 74 T.C. at 354.

290. Id. at 355.

291. Id.

292. Id.

293. Cf. Starker v. United States, 602 F.2d 1341, 1355 (9th Cir. 1979) ("[T]jtle to real property, like a contract to purchase real property, is nothing more than a bundle of potential causes of action: for trespass, to quiet title, for interference with quiet enjoyment and so on.").

294. Hilton, 74 T.C. at 360. 
retire the balloon that would have to be refinanced in year thirty-one. ${ }^{295}$ The court considered any cash flow to the lessor after fifty-three years to be insignificant both because it was too speculative and because the amount would be very small when discounted to present value. ${ }^{296}$ The favorable lease renewal options deprived the lessor of meaningful opportunities to sell or to refinance the property, and any profit to the lessor from condemnation was based on events outside the lessor's control and was too speculative to be considered. ${ }^{297}$ Finally, the court noted that nothing was contributed to the property-or paid to the seller-lessee-by the SPE or its assignees. On the other hand, the seller-tenant made substantial expenditures related to the property that were not reimbursed. 298 The tenant "dealt with the transaction in this respect in the same manner as it would have done as the true owner of the property; it financed as much of the cost as possible and paid the balance from its own funds." 299

In summary, the Tax Court in Hilton concluded that there was no genuine multiparty transaction within the meaning of Frank Lyon Co. ${ }^{300}$ The SPE was merely a conduit through which the tenant's debt service passed. "It follows that [the assignees of the SPE] have no 'investment' in the property upon which depreciation can be predicated; it also follows that the debt in question has no economic significance to [the assignees] and thus they have not, in this case, secured "the use or forbearance of money." 301 The true investor was the tenant, and the lease reflected its mortgage.

\section{The 1999 Advice and the Continued Importance of Sun Oil and Hilton}

The 1999 Advice 302 directly addressed the phenomenon of synthetic lease transactions. In a situation presenting "a difficult and close call," the Service applied a benefits and burdens analysis to vindicate a tenant's claim to depreciation deductions. ${ }^{303}$ The Service cited, among other things, that the tenant directed all acquisitions and construction, the "symbiotic relationship" between the SPE and the tenant, that the lending was based "exclusively on the credit worthiness" of the tenant, that the tenant structured the transactions for financial accounting reasons, and that both the SPE and the tenant consistently reported that the tenant was the substantive owner and borrower for federal income tax purposes. ${ }^{304}$

295. Id. at 356.

296. Id.

297. Id. at 359:

[T] he possibility of condemnation for a substantial amount of money, sometime in the future, of a major installation such as a department store building is not, in and of itself, the sort of speculative chance to which even incorrigible gamblers - which we assume these petitioners are not-would likely be attracted.

298. Id. at 360 .

299. Hilton, 74 T.C. at 360.

300. Id.

301. Id. at 364 (quoting Estate of Franklin v. Commissioner, 544 F.2d 1045, 1049 (9th Cir. 1976)).

302. See Advice, supra note 4.

303. Id.

304. Id. 
The Advice's "flexibility on this issue" has been called "surprising." 305 To the contrary, the Advice reflects the Service's attempt to preserve prior victories limiting the ability of taxpayers to elevate form over substance. In particular, the Advice reflects the enduring importance of the considerations and analysis of Sun Oil and Hilton. ${ }^{306}$

Sun Oil is important because it considers all the provisions allocating rights and responsibilities between landlord and tenant and how they are likely to be implemented as a practical matter. It looks, for example, at the practicality of a particular lessor rejecting "rejectable" offers to purchase, of a lessee declining to exercise an option to purchase, or of either party conducting expensive or time-consuming appraisals. It also considers the full range of provisions that permit a tenant to act as owner, for example, by authorizing it to negotiate with governmental authorities or otherwise assert the rights of an owner. It looks at whether skids are greased one way or the other, for example, by offers that are deemed accepted if they are not quickly rejected. Finally, it also indicates that an ex post analysis is appropriate: how the parties consistently behave is a good indication of what they initially intended.

Hilton is important because it reverses the Service's crushing defeat in Bolger ${ }^{307}$ and applies Frank Lyon Co. ${ }^{308}$ narrowly to a paradigmatic consensual leasing transaction. ${ }^{309}$ Hilton stands for the important proposition that a transaction must be evaluated both from the point of view of the lessee and from the point of view of the SPE. Granted, no single model of "ownership" can apply to all commercial leasing transactions. Nevertheless, an SPE will not be treated as the owner for tax purposes if the tenant has the great bulk of the benefits and burdens of ownership. As a result, an SPE or other orchestrator of a financing transaction may not be paid in depreciation deductions. ${ }^{310}$ Perhaps this principle is less critical after the enactment of the passive loss rules in 1986,311 but it is critical nonetheless. Depreciation deductions may not be "stripped" from the person who has virtually all of the benefits and burdens of ownership and assigned to someone else. This may not be done generally under our tax law and it should not be done at the insistence of the Service simply to end the benefits of synthetic lease transactions that at first blush seem too good for taxpayers to be true. If something is broken, it is the financial accounting standards, not the benefits and burdens analysis of federal income tax law.

305. "Synthetic Lease," Approved by IRS, Offers Off-Book Financing, 91 J. TAX'N 123, 123 (1999).

306. See Sun Oil v. Commissioner, 562 F.2d 258 (3d Cir. 1977); Hilton v. Commissioner, 74 T.C. 305 (1980), aff'd per curiam 671 F.2d 316 (9th Cir. 1982).

307. Bolger v. Commissioner, 59 T.C. 760, 771 (1973).

308. Frank Lyon Co. v. United States, 435 U.S. 561 (1978).

309. See Hilton, 74 T.C. at 346.

310. See generally Bolger, 59 T.C. at 760.

311. See I.R.C. $\$ 469$ (1986). The passive loss rules limit the deduction of passive activity losses to income from similarly passive sources, in effect denying their use against compensation for personal services and other portfolio income. 


\section{CONCLUSION}

\section{A. In General}

Synthetic lease transactions are currently very popular, especially among public companies. When successful, they permit a company to achieve off-balance sheet financing by reporting merely an operating lease rather than an asset encumbered by a mortgage. At the same time, the company reports for federal income tax purposes that it owns an encumbered asset used in its trade or business, thus entitling it to depreciation deductions. In a typical synthetic lease transaction, the parties agree that the tenant, not the landlord, is the party who will consistently report an investment in a depreciable asset for federal income tax purposes.

There is nothing inherently wrong with a lessee claiming that it has made a depreciable investment in real estate it is nominally leasing. This is true even if, under financial accounting standards, the lessee is disclaiming both the debt and the asset. There is not necessarily anything "broken" that needs fixing simply because there are different positions taken for tax and for financial accounting purposes.

\section{B. Federal Tax Law}

The federal income tax law does not need fixing. It has been remarkably consistent over the decades and remains on target. In the world of commercial real estate finance, there is no single, simple concept of ownership. Rather, the tax law says what state property law says, which is that ownership must be analyzed more carefully. Property rights are analogized to a bundle of sticks, and the tax question is whether a claimant to depreciation deductions has enough of the sticks-the benefits and burdens of ownership-to support a claim to the otherwise nonassignable depreciation deduction. Because more than one party in a commercial leasing transaction may be plausibly considered an owner, the parties have some flexibility to allocate benefits and burdens in a way that supports a claim to an investment in a depreciable asset. That flexibility, however, should not be overstated. At bottom, there is no basis for concluding that the depreciation deduction is assignable away from the one person in a transaction who has the overwhelming bulk of the benefits and burdens of ownership.

It is appropriate for the Service to scrutinize synthetic lease transactions for their economic substance. Not only does the taxpayer seek to disregard its own choice of transactional form, it does so by arguing that the economic substance of the transaction is fundamentally different from the one it reports for financial accounting purposes. Nevertheless, the Service should exercise restraint in challenging the appropriateness of the tenant's claim to depreciation deductions. The Service should avoid taking a position that would inadvertently jeopardize its earlier victories emphasizing the importance of a benefits and burdens analysis. In particular, the Service must protect its victory in Hilton that says an orchestrator of a financing transaction may not be compensated by an assignment of depreciation deductions from a lessee who holds virtually all of the economic benefits and burdens of ownership. Stated differently, in order to protect against improper assignments of income, the Service must preserve Sun Oil's scrutiny of the total, practical relationship between lessor and lessee and Hilton's more narrow 
reading of Frank Lyon Company's suggestion that taxpayers may select substance with form.

\section{Financial Accounting Standards}

Unlike the federal income tax law, the financial accounting standards have been less stable and definitely need fixing. Most simply, FASB currently permits enormous amounts of debt to vanish from a company's balance sheet. Corporations are permitted to appear far less leveraged than they are by recasting mortgages as leases. In a system that prides itself on transparency, this transactional sleight-of-hand should not be permitted.

There is no easy solution. By their very nature, the financial accounting standards try to draw clear lines. Clear lines invite side-stepping. FASB has worked for years gradually improving the system of accounting for leases. Improvement will be incremental, and it is hard to imagine a set of accounting rules that would balance all the factors discussed in the case law.

Nevertheless, at least two basic steps should be taken to curb the use of synthetic lease transactions to keep billions of dollars of debt off corporate books. First, FASB should eliminate the dramatic distinction between sale-leasebacks and other financing transactions. It should follow the lead of state mortgage law, which makes no such distinction. To some extent, FASB has narrowed the distinction indirectly, by requiring certain tenants to consolidate their reporting with SPEs. The narrowing should continue to the vanishing point. There is no reason that sale-leasebacks should pass much more rigorous standards than third-party acquisitions by SPEs. Second, and more immediately, FASB should require full disclosure by the lessee when the lessor and lessee have agreed that, for federal income tax purposes, the lessee will claim that it owns the encumbered asset.

There are those in the accounting profession who might object to this second suggestion on the ground that FASB should not base financial accounting treatment upon federal income tax classification. There are two basic responses. First, in this area, FASB would not be building on shifting sands. The basic rules of the federal income tax classification of leases as mortgages have remained remarkably stable. A benefits and burdens analysis has been the prevailing analysis for at least the past fifty years and is not likely to change. Second, the proposed change need not be viewed as basing financial accounting on tax classification. Rather, the change would simply require a tenant to disclose that it has a contractual understanding that it, rather than the landlord, will report to government officials that it owns the encumbered asset. 
